Illinois State University

ISU ReD: Research and eData

Theses and Dissertations

Fall 12-2001

\title{
A Curriculum Design for Sport Tourism Studies in South Africa
}

Kamilla Swart

Illinois State University

Follow this and additional works at: https://ir.library.illinoisstate.edu/etd

Part of the Curriculum and Instruction Commons

\section{Recommended Citation}

Swart, Kamilla, "A Curriculum Design for Sport Tourism Studies in South Africa" (2001). Theses and Dissertations. 644.

https://ir.library.illinoisstate.edu/etd/644

This Dissertation is brought to you for free and open access by ISU ReD: Research and eData. It has been accepted for inclusion in Theses and Dissertations by an authorized administrator of ISU ReD: Research and eData. For more information, please contact ISUReD@ilstu.edu. 


\section{A CURRICULUM DESIGN FOR SPORT TOURISM \\ STUDIES IN SOUTH AFRICA}

KAMILLA SWART

A Dissertation Submitted in Partial

Fulfillment of the Requirements for the Degree of

DOCTOR OF EDUCATION

Department of Curriculum and Instruction

ILLINOIS STATE UNIVERSITY

2001 


\title{
A CURRICULUM DESIGN FOR SPORT TOURISM \\ STUDIES IN SOUTH AFRICA
}

\author{
Kamilla Swart
}

\section{Pages}

December 2001

The focus of this study is the design of a sport tourism curriculum for post secondary education in South Africa. From a review of literature. it was determined that there are many performance problems in the sport tourism industry in South Africa. This same review revealed that the performance problems are a function of the lack of formal provisions for sport tourism education in South Africa.

As sport tourism is progressing encouragingly as an academic discipline. an analysis of various curriculum offerings worldwide was conducted. It is contended that the current offerings are deficient to meet the future requirements of the sport tourism industry within South Africa. Hence it is necessary to design and implement a curriculum that will allow sport tourism professionals to resolve the performance problems within South Africa's sport tourism industry.

An integrated approach to the design of the curriculum was then employed to (1) determine the principal features of a sport tourism curriculum that is best suited to the task of improving the performance of South African sport tourism professionals and (2) determine the delivery system for the sport tourism curriculum. The educational experience was designed in a form of a curriculum. "Sport Tourism Studies", and the 
delivery format was modules via the Internet. This design is justified on the basis that it has the greatest potential to meet the intent and principles. and content of the proposed curriculum design for sport tourism studies in order to resolve performance problems in the sport tourism industry. As the method used to design the sport tourism curriculum is an iterative process. a necessary step in the implementation process is to determine how successful the program is. 


\section{ACKNOWLEDGEMENTS}

The writer wishes to acknowledge the efforts of some individuals without whom this dissertation would not have been possible. To my family and friends, thank you for your continued support and encouragement. A special thank you to Ellen and Barb who took care of my obligations in Illinois while I was completing this dissertation in South Africa. To Pierre. I owe a great debt of gratitude for seeing us through this challenge. I must also thank my dissertation chair. Dr. Dent Rhodes, and my committee members. Dr. Al-Bataineh, Dr. Jerrich and Dr. Turco for contributing to my greater understanding of sport tourism and curriculum achieved during the development of this dissertation.

Finally, I would like to thank Nadia for her assistance with the type-setting and Brad and Urmilla for their assistance in the editorial process during the latter stages of completion of this project.

K.S. 


\section{CONTENTS}

Page

ACKNOWLEDGEMENTS

CONTENTS

TABLE vii

FIGURES viii

CHAPTER

I. SPORT TOURISM AND SPORT TOURISM EDUCATION

Performance Problem 2

Education Problem 5

Curriculum Problem 6

Problem for Study $\quad 7$

Objectives $\quad 7$

Research Questions $\quad 8$

Conceptual Framework $\quad 8$

Definitions of Significant Terms $\quad 14$

$\begin{array}{ll}\text { Methodology } & 18\end{array}$

Limitations of Study $\quad 19$

Significance of Study $\quad 19$

Additional Chapters $\quad 21$

II. REVIEW OF LITERATURE 22

Curriculum Design $\quad 22$

Subject-Centered Designs $\quad 27$

Learner-Centered Designs $\quad 28$

Problem-Centered Designs $\quad 28$

$\begin{array}{ll}\text { Design Dimension Considerations } & 28\end{array}$

ii 
Scope

Integration

Sequence

Articulation

Balance

Continuity

Sport Tourism Curricula

Type of Academic Programs

Degrees or Certificates Offered

Academic Departments

Course Titles

Course Title Analysis $\quad 38$

Recreation courses

Management courses

Tourism courses

Sport tourism foundation courses

39

Sport tourism management courses

Sport tourism law courses

41

Sport tourism finance courses

Specialization courses

Sport tourism projects and dissertation

Rationale, Aims and Objectives

Introduction to Sport Tourism

Preparation for the Sport Tourism Industry

Educational Processes

Future Courses or Programs

Analysis of Sport Tourism Curricula with Respect to Curricular Components 
Government Policy Papers on Sport and Recreation

Government Policy Papers on Tourism

Development and Promotion

South Africa Sports Tourism Campaign

Sport Tourism Strategies

65

Activity holiday centers

65

Sport camps

65

Sport tours

66

Sport tourism as an economic development strategy

Education Problem

Curriculum Problem

Problem for Study

Curriculum Context

Significant Features of the Curriculum

Context

Significant Tasks in the Referent Situation

Formulation

Curriculum Problem to be Resolved

Conceptualize "Sport Tourism"

Demonstrate Best Practice in Developing,

Bidding and Hosting Sport Tourism

Events

Demonstrate Best Practice in Developing

Sport Tourism Initiatives

Demonstrate Best Practice in Developing

Sport Tourism Marketing Plans for an

Event or Destination

Demonstrate an Understanding of Potential

Positive and Negative Impacts of Sport

Tourism 
Demonstrate Best Practice in Developing

Sport Tourism Strategies for

Destinations

Demor.strate Skills of Evaluating Sport

Tourism Initiatives

87

Demonstrate Skills of Written Reporting of

Sport Tourism Problems and Issues

88

Ways to Resolve the Curriculum Design

Problem

90

Devise and Assess Alternative Resolutions for

Each Curriculum Design Problem

90

Select the Most Suitable Resolution for Each

Curriculum Design Problem

94

Execution

95

Realize the New Design

Sport Tourism Studies Curriculum (Scope

and Sequence)

Explanation for selected scope and sequence

Sport Tourism Studies Curriculum

(Delivery)

Explanation for chosen curriculum delivery format

Problem Resolution

Review

Revision

IV. SUMMARY, CONCLUSIONS AND

RECOMMENDATIONS

The Problem Under Consideration

123

Objectives

Summary: Objective 1

Summary: Objective 2 
Summary: Objective 3

Summary: Objective 4

Summary: Objective 5

131

Summary: Objective 6

131

Summary: Objective 7

Summary: Objective 8

135

Summary: Objective 9

Conclusions

Recommendations 


\section{TABLE}

Table

Page

1. Impacts of Sport Tourism Events

69

vii 


\section{FIGURES}

Figure

Page

1. Interrelationship of Determinants in Curriculum Development

25

2. Curriculum Articulation

31

viii 


\section{CHAPTER I}

\section{SPORT TOURISM AND SPORT TOURISM EDUCATION}

Sport tourism is one of the fastest growing segments of the global tourism industry (Delpy. 1996). Since the first democratic elections in 1994. South Africa has experienced a dramatic increase in tourism. attributed in part to hosting a number of higher profile sport events. The marketing of sport events has become particularly important in an effort to achieve growth in the tourism industry. To maximize South Africa's tourism potential. the government launched a sport tourism campaign. South Africa Sports Tourism (SAST) as part of a theme-based initiative. SAST has been conceived to act as an umbrella enterprise under which existing events may receive unified promotional support. additional sporting events and recreational activities can be developed to the greatest benefit of the tourism sector. and the country's extensive recreational resources can be publicized to potential international and domestic tourists (SAST. 1998). Despite the developments made in implementing SAST themes and objectives through particular programs, the campaign faces a number of barriers to its growth and success. In order to enhance the SAST campaign. it will be desirable for sport tourism professionals to perform tasks better than they do now. 
Performance Problem

There are many performance problems within the sport tourism industry in South Africa. A significant challenge for sport tourism professionals is to develop sport tourism more effectively as an economic development strategy. It is necessary for them to be able to understand the socio-economic costs and benefits of sport tourism. Sport tourism professionals should be able to bid for events more effectively. and host events more successfully. It is also necessary to make use of existing sport tourism infrastructure more efficiently. An understanding of the sport tourism consumer from a sports perspective will be beneficial. A sustainable sport tourism industry further requires the identification of the benefits sought by sport tourists and the elements that appeai to various market segments, and better management of the needs of the sport tourist.

Since South Africa's re-admission to international sport it has hosted a number of higher profile sport events such as the Rugby World Cup (1995), African Nations Cup of Soccer (1996). World Cross Country Championships (1996). Modern Pentathlon World Cup Final (1996). UCI Mountain Bike World Cup Downhill (1997) and the World Cup of Golf (1997). It is evident that South Africa's use of sport tourism as an economic development strategy is limited as it focuses on major events only. Smaller and more regular events should be incorporated into the SAST campaign. These events, then, can provide a more secure basis for the long-term development of South Africa's sport tourism industry. It is contended that destination marketers should cautiously consider developing an appropriate and attractive portfolio of sport events in which the occasional mega-event is offset by embarking on lesser, infrequent events and frequent local or 
regional-scale events (Getz, 1998). He adds that many communities can never aspire to host the world's largest events but they can nevertheless create a suitable niche in smaller scaled events. Presently. the SAST campaign makes no explicit reference to smaller scaled-events and the promotion of sport tourism on a regional level.

While leading cities in South Africa are bidding to host major sport events many have not taken into consideration that South African society currently do not have the expertise to host these events. In fact. the White Paper of the Government of South Africa Department of Sport and Recreation (1996) has identified it as an area of weakness in the administration of South African sport. Moreover. this lack of expertise was evident in the failed Cape Town Olympic bid for the 2004 Games.

As bidding for major events have become very competitive. it is necessary to justify the bid effort. knowing that there is likelihood for potential losses (Getz. 1998). This is a significant question for Olympics and other global-scaled event bids. as the bid effort can readily cost millions of dollars over a multiyear period (Getz, 1998). He adds that agencies and communities considering major bids should do so with a strategy to achieve benefits to the community beyond the attainment of the hosting privilege. Considering South Africa's lack of expertise with the bidding and hosting of major international sport events. the 2004 Olympic bid was premature and could have resulted in significant costs to the community.

This lack of expertise continues to be evident in the hosting of recent events such as the Afro-Asian football (soccer) international between South Africa and Saudi Arabia in Newlands. Cape Town and the All Africa Games in Johannesburg. Both these events 
took place in September 1999, and were marred by inefficient use of infrastructure (personal communication, B. Walters, November 5, 1999). The failure to attract capacity crowds to an international football match at Newlands was evident. It is cortended that a different approach to marketing football events at Newlands should be undertaken. as it is a stadium traditionally used for rugby only. In addition to the lack of spectators at many events at the All Africa Games. other organizational hitches included accreditation. accommodation. and volunteer problems (personal communication. B. Walters, November 5. 1999). These performance problems undoubtedly had an effect on the total experience of the sport tourism consumer. This indicates that it is necessary to understand the sport tourism consumer from a sports perspective better. to be able to identify the benefits sought by sport tourists and the elements that appeal to various market segments. and to manage the needs of the sport tourist better.

The SAST campaign has failed to make a significant impact on tourism development in South Africa due to a lack of government financial support. a lack of communication between sport and tourism bodies. and a lack of forward planning and communication by tourism bodies (SAST. 1998). It is contended that a lack of understanding and awareness of the benefits of a closer link between sport and tourism bodies contributes to this scenario. It is interesting to note that government is no longer giving financial support to the SAST campaign (personal communication, C. Haber, September 2. 1999). Moreover. a recent survey conducted by Swart (1999a) concerning the potential development of adventure sport tourism in the Western Cape confirmed that 
there is a definite lack of communication and coordination between sport and tourism bodies concerned with adventure sport in the Western Cape.

\section{Education Problem}

The performance problems alluded to above are a function of the lack of formal provisions of sport tourism education in South Africa. With the sport and tourism industries moving closer together in recent years. educational establishments have been left short in meeting the requirements of industry to provide graduates who understand the consumer from a sports perspective. and with the ability to manage the needs of the tourist (Gammon \& Robinson. 1999). This is particularly apparent in South Africa. as there are no opportunities available for sport tourism education.

The Government of South Africa Tourism White Paper (1996) identifies the absence of adequate education. training and awareness as perhaps the greatest deficiency in the tourism industry in South Africa. Furthermore, it advocates the development and investment in an education system that will lead to self-sufficiency and reduce reliance on imported skills as one of the main pillars of a new responsible tourism industry in South Africa (Government of South Africa: Department of Environmental Affairs and Tourism [DEAT], 1996).

Sport tourism has been identified as a strategy to grow the tourism sector as a major force in the national economy. The Minister of Environmental Affairs and Tourism (personal communication, January 18, 1998) corroborates the importance of studies in sport tourism "since there is no doubt that this market segment holds 
tremendous growth potential for our country". Although trade education. training and research are identified as SAST campaign products. there has been little emphasis on these aspects. The introduction of sport tourism education is desirable, as it will contribute to a body of knowledge that is necessary for sustainable tourism to flourish in South Africa. The White Paper on Tourism (1996) concludes that if tourism contributed $10 \%$ to the GDP (Gross Domestic Product) of South Africa. as it does in the USA. the industry would generate some R48 billion (\$US 8 billion) annually and create two million jobs. The introduction of sport tourism education is desirable in terms of its contribution to the development of a sustainable sport tourism industry.

\section{Curriculum Problem}

The education problem is a curriculum problem in that persons cannot get information. skills and dispositions necessary to participate effectively in the sport tourism industry. Presently, there is one sport tourism module being offered at one university in South Africa. Few higher education institutions involved in sport and tourism recognize the importance of introducing sport tourism as a discipline at this level. Recently, an introductory sport tourism course was taught to tourism students in Cape Town. They strongly contended that they were being denied an opportunity to be exposed to a niche market as sport tourism is not currently offered as part of their tourism studies. Moreover, there is a feeling that current sport management departments do not have the expertise in this field. The author therefore recommends that in order for the SAST campaign to have a significant and sustainable impact on South African society, greater 
emphasis on education is required. It is further contended that the development of a sport tourism curriculum (and ultimate implementation) will contribute to the sustainable development of the sport tourism industry in South Africa.

\section{Problem for Study}

The problem to be investigated can be defined as the discrepancy between the lack of a sport tourism curriculum for a particular clientele. in a specific context. and with a specific content in South Africa and the desirability of a sport tourism curriculum for a particular clientele, in a specific context. and with a specific content in South Africa.

\section{Objectives}

The general objective of this study is to develop a sport tourism curriculum so that persons can get the relevant information. skills and dispositions necessary for effective participation in the sport tourism industry. The specific objectives of this study are to:

1. Identify a curriculum design and development model appropriate for a sport tourism curriculum.

2. Describe the current status of sport tourism curricula.

3. Provide a rationale for developing a sport tourism curriculum.

4. Identify the specific context for the sport tourism curriculum.

5. Identify the particular clientele for the sport tourism curriculum.

6. Identify the specific content for the sport tourism curriculum.

7. Determine the scope of the sport tourism curriculum. 
8. Determine the sequence of the sport tourism curriculum.

9. Determine the delivery system for the sport tourism curriculum.

\section{Research Questions}

These objectives translate into the following research questions:

1. What is an appropriate curriculum design and development model for a sport tourism curriculum?

2. What is the current status of sport tourism curricula?

3. What is the rationale for developing a sport tourism curriculum?

4. What is the specific context for the sport tourism curriculum?

5. What is the particular clientele for the sport tourism curriculum?

6. What is the specific content for the sport tourism curriculum?

7. What is the scope of the sport tourism curriculum?

8. What is the sequence of the sport tourism curriculum?

9. What is the delivery system for the sport tourism curriculum?

\section{Conceptual Framework}

In order to gain insight into what is known about curriculum design and sport tourism, a search of the educational and sport tourism literature will be undertaken. respectively. Similarly, sport tourism and educational literature will be searched to determine why it should be implemented as a curriculum. To identify the specific context, clientele, and content for the sport tourism curriculum. the same literature bases 
will be searched. In order to determine the scope, sequence and the curriculum delivery system of the sport tourism curriculum. curriculum design and development literature. and adult and continuing education literature will be searched.

The concept of curriculum design focuses on the ways in which curricula are created. particularly the actual arrangements of the parts of the curriculum plan (Ornstein \& Hunkins. 1998). The parts or components of the curriculum plan include (a) objectives, (b) subject matter. (c) method and organization, and (d) evaluation (Giles. McCutchen \& Zechiel. 1942). Posner and Rudnitsky (1990) assert that any systematic approach to developing curricula should be considered within the context of a theoretical framework. Curriculum components can be organized in various ways. However. most curriculum designs are modifications or integrations of three basic design types: (a) subject-centered designs. (b) learner-centered designs. and (c) problem-centered designs (Ornstein \& Hunkins. 1998). While it is beyond the scope of this chapter to outline these approaches. it is contended that these designs are limited as they load on a specific component of the curriculum. Taba (1962) noted that most curriculum designs contain the four components mentioned above. but that many lack balance as the elements are poorly defined or are not considered in relation to a theoretical rationale.

The components of a curriculum can be viewed along several dimensions. These dimensions include (a) scope. (b) integration, (c) sequence. (d) continuity. (e) articulation. and (f) balance (Ornstein \& Hunkins. 1998). The breadth and depth of the curriculum content is generally referred to as its scope. A major challenge when dealing with scope is the linking of all types of knowledge and experience within the curriculum 
plan. This linking of activities is referred to as integration. Ornstein and Hunkins assert that in order for the curriculum to encourage cumulative and continuous learning attention is paid to the vertical relationship or the sequence of the curricular elements. They further define continuity as the vertical manipulation or repetition of curriculum components whereas the inter-relatedness of various aspects of the curriculum is referred to as articulation. and can be either vertical or horizontal. Balance refers to the concern that appropriate weight is given to each aspect of the design in order to prevent distortions. Tanner and Tanner (1995) identify balance as to the degree to which the curriculum is in harmonious proportion.

Traditionally. curriculum development has been concerned with Tyler s (1949) four fundamental questions as listed below:

1. What educational purposes should the school seek to attain?

2. What educational experiences can be provided to attain these purposes?

3. How can these educational experiences be effectively organized?

4. How can we determine whether these purposes are attained? Slattery (1995) reports that Tyler's questions have dominated the study of curriculum over the past fifty years. As noted previously. Taba (1962) asserted that most curriculum designs contain these four components, however many lack balance as the elements are poorly defined or are not considered in relation to a theoretical rationale. Sport tourism is advancing encouragingly as an academic discipline, particularly in the USA, and the industry has increasingly recognized the necessity for quality management, professional career structures and better retention rates throughout its 
operations and sectors. (University of Luton, 1998). Sport tourism programs are also being implemented at post secondary institutions in Europe and Australia. An understanding of sport tourism is essential to the development and design of a sport tourism curriculum. Sport tourism professionals are required in a broad range of areas within the industry. A sport tourism curriculum is necessary to provide professionals with the opportunity to develop the knowledge and competencies required for employment within the sport tourism industry.

As the curriculum is intended to resolve performance problems in the sport tourism industry, the clientele will be the adult learner. An understanding of adult learning principles is necessary. For adult learners, learning is more than just the acquisition and manipulation of content. Knowles' core principles of androgyny enable those designing adult learning to build more effective learning processes for adults (Knowles. Holton \& Swanson. 1998). They add that these core principles include:

1. the learner's need to know;

2. self-concept of the learner;

3. prior experience of the learner:

4. readiness to learn;

5. orientation to learning; and

6. motivation to learn.

Principles that will guide the curriculum design process are linked to the adult learning principles mentioned above. The instructional principles as outlined by Palmer 
and Rhodes (1997) articulated as curriculum principles for the purposes of this dissertation, include the following:

1. meaningful application;

2. manageable expectations;

3. performance examples;

4. active participation;

5. practice opportunities;

6. knowledge of progress:

7. opportunities for choice;

8. opportunities for success; and

9. supportive environment

It is necessary to review specific sport tourism curricula. Sport tourism is progressing encouragingly as an academic discipline worldwide. The University of Luton who have instituted a sport tourism degree program in recent years notes that the sport tourism industry has recognized the importance of quality management throughout its operations and sectors (University of Luton, 1998). Sport tourism programs are also being implemented at post secondary institutions in the USA. Europe and Australia (Swart. 1999b). Gammon and Robinson (1999) note that a number of factors require consideration in the development and design of the broadly defined elements of the sport tourism curriculum. They further report that it is essential to notify would-be developers and designers on issues concerning the nature and evolution of the sport tourism 
curriculum. Gammon \& Robinson add that this will more than likely stimulate debate concerning the core curriculum. design and development of this new and emerging field. An understanding of sport tourism is essential to the development and design of a sport tourism curriculum. In order to identify the components of a sport tourism curriculum. it will be beneficial to understand what is meant by sport tourism in order for the curriculum to meet the future requirements of the sport tourism industry.

Given the limited research concerning sport tourism curricula, a study was conducted by Swart (1999b) to determine the scope of sport tourism courses. modules. programs or degrees that are currently being offered by academic institutions. Although both the sport tourism curricula implemented in the United Kingdom and Australia is specific to their particular cultural context, they both seem to be designed according to the "conventional" approach that draws upon applied psychology and educational craft wisdom for prescribing solutions to education problems. Gammon and Robinson (1999) noted that knowledge and expertise were sought from various international institutions. An element of the "marketing" approach was also apparent as the curricula were based upon the perceptions of what the sport tourism industry wants or needs. The author contends that current sport tourism curricular offerings are deficient to meet the future requirements of the sport tourism industry within South Africa. It is necessary to design and implement a curriculum that will allow sport tourism professionals to resolve the performance problems within South Africa's sport tourism industry. This will determine the scope of the sport tourism curriculum, as this knowledge will be considered most worth. The most appropriate sequence that will give balance to the curriculum will be 
identified. Thus a curriculum design appropriate for the next decade of sport tourism in South Africa is envisioned.

It is contended that problem-directed design or enterprise-directed design would be most suitable to design the sport tourism curriculum. The "model" or "conception" of instructional design that will be utilized to develop the sport tourism curriculum is Rhodes` Problem-Directed Instructional Design (Byers \& Rhodes. 1998). Although it is essentially an instructional design model. this approach is favored as an alternative to conventional curriculum design models. The generic design is problem or solution oriented. According to this conception of instructional design. as described by Byers and Rhodes. the design of instruction is regarded as a systematic process by which a series of problems in the design context are identified. defined and resolved. The problem guides design efforts rather than one accepted approach to problem solving. Gentry (1991) notes that the designer has greater latitude. and the likelihood of finding the best solution to the problem is greatly enhanced. Problem-directed design consists of five major components: (a) preparation. (b) formulation. (c) execution. (d) review, and (e) revision (Byers \& Rhodes. 1998). These components are conceptually distinct. however the design process is recursive. They will be used to answer questions two to nine that are concerned with design considerations.

\section{Definitions of Significant Terms}

In order to develop a sport tourism curriculum, it necessary to first determine what is meant by sport tourism. Defining sport tourism is clearly problematic as it is 
combined by two already unclear terms to make one that is doubly ambiguous (Gammon \& Robinson, 1999).

Sport has been defined in many ways. It typically refers to physically oriented activity guided by an organized format and rules that are imposed by participants or an organized body that represent the sport. The goals of the sport are usually to beat an opponent, compete against a standard of performance, or achieve a predetermined goal. However. a broader and more diverse definition of sport is required when addressing sport tourism. According to this definition. sport is an activity, experience or production for which the primary focus is athletics or physical recreation.

Until a few years ago, a singular definition of tourism was blurred. In 1991. the World Tourism Organization (WTO) hosted the International Conference on Travel and Tourism Statistics to address the problem of common definitions. The tourism definitions listed below are the results of the 1991 conference held in Ottawa. Canada. WTO defined tourism as the following: Activities of a person traveling to a place outside his of her usual environment for less that a specified period of time with a main purpose other than the exercise of activity remunerated from within the place visited where:

- the 'usual environment' was meant to exclude trips within the place of residence and routine trips such as traveling a long way to and from work on a daily basis;

- the "less than specified period of time" was meant to exclude long-term migration such as people who travel to another country to live; 
- the 'exercise of an activity remunerated from within the place visited' was meant to exclude migration for temporary work. (p. 3)

Now that sport and tourism has been defined. it is necessary to define sport tourism. One of the main discussions to arise is whether to use the term sport or sports. Presently, in the literature sport tourism and sports tourism are being used interchangeably (Gammon \& Robinson, 1999). However, as noted by Parks and Zanger (1990) when discussing the difference between sports and sport management. sports suggest a collection of separate activities. In contrast. sport is a collective noun that includes all activities that meet the standards. Therefore. as contended by Gammon and Robinson. sport tourism is a considerably broader concept that embraces sport as being both recreational and competitive, and institutionalized and transitory. In contrast, sports tourism is limited as it focuses upon competitive sporting travel. A number of definitions of sport tourism provided by various authors such as Kurtzman and Zauhar (1997) and Delpy (1998) suggest that sport tourism entails the study of the predetermined or incidental participation or attendance of sports based activities, by individuals or groups outside their home environment (Gammon \& Robinson, 1999). This broad framework will be utilized to structure the development of the sport tourism curriculum.

There are many competing definitions of the term curriculum. It stems from the Latin word "currere" which means to "run the course" (Wiles \& Bondi. 1993). They add that. over time. the traditional definition of the curriculum meant "the course of study". Ratcliff (1997) asserts that answering what a curriculum is and what it should be is essential to understanding and enhancement. He adds that the term curriculum refers to 
an educational plan of an institution. a school. a department. a program. or to a course. Moreover. Ratcliff notes a course is used generically to indicate a formal unit of the curriculum. Faculty usually design and teach these courses singularly. The role of the course in the curriculum at the inception is largely determined through a review by colleagues. and subsequently at an institutional level. It is presumed that if the new course does not significantly duplicate others. it has merit as a contribution to and representation of the expanding knowledge base (Ratcliff, 1997). Furthermore he notes. in contemporary post secondary institutions, faculty members usually design and conduct the learning experiences that are referred to generically and collectively as the curriculum.

Pratt (1980) defines a curriculum as a systematic set of formal education and training intentions. In contrast, Toombs and Tierney (1991) note that a curriculum can be viewed as a plan for learning, an instructional system, and an important subsystem of the university and an instrument of student development. Ratcliff (1997) recommends that an operational definition be chosen to furnish a context when designing curriculum.

In summary, there are four common definitions of curriculum. These include curriculum as subject matter. curriculum as a plan. curriculum as an experience, and curriculum as an outcome (Wiles, 1999). It is further contended that any definition of curriculum must go beyond a statement about the knowledge-content to an explanation, and indeed a justification, of the purposes of such transmission and an exploration of the effects that exposure to such knowledge is likely to have or is intended to have (Kelly, 1999). For the purposes of this study, curriculum will be defined as all the planned 
conditions and events to which the person is exposed for the purposes of promoting learning plus the framework of theory which gives these conditions and events a certain coherence (Travers, 1964). In this way, teaching methods and the contents of the teaching-learner encounter make up the curriculum.

In South Africa, the term football refers to the sport of "soccer". to which most Americans are accustomed. As indicated by Masteralexis, Barr and Hums (1998). this terminology is used intentionally as football does not mean American football in the majority of the world, but instead to the traditional sport played at the much anticipated and celebrated Football World Cup.

\section{Methodology}

To answer the first research question, a search of the education literature will be undertaken to gain an insight into what is known about curriculum design. To answer the second question to determine what is the current status of sport tourism curricula. a search of the sport tourism literature will be undertaken. To answer the third research question concerning the rationale for developing a sport tourism curriculum, the sport tourism and educational literature will be searched. Rhodes' Problem-Directed Instructional Design model as outlined in Byers and Rhodes (1998) will be employed to address research questions four to nine. Specifically. the preparation phase of instructional design model will be used to answer research questions four and five. that is to identify the specific context for the sport tourism curriculum, and to identify the particular clientele, respectively. To identify the specific content for the sport tourism 
curriculum. research question six, the formulation phase of the instructional design model will be used. The execution phase will be utilized to determine the scope (research question seven), sequence (research question eight) and delivery system (research question nine) of the sport tourism curriculum. To assess the scope. sequence and delivery system of the sport tourism curriculum, the review phase will be used.

\section{Limitations of Study}

The results of this study are specific to the design context and no claims of applicability beyond this context will be made. The sport tourism curriculum that is to be developed will only apply for a particular clientele in a specific context.

\section{Significance of Study}

The tremendous growth in sport tourism over the last decade has left educational establishments lagging behind in meeting the requirements of the sport tourism industry. By developing a sport tourism curriculum, this study will identify core aspects of sport tourism and integrate these within the local framework of development in an attempt to address this concern in South Africa.

Apartheid had a significant impact on education in South Africa. Presently, a chronic mismatch exists between higher education output and the needs of a modernizing economy (Government of South Africa: Department of Education and Training [DET]. 1996). It further adds that there is a shortage of highly trained graduates in various fields, largely as result of previous discriminatory practice. One of the primary objectives in 
post secondary education in South Africa will be to produce the skills and technological innovations necessary for successful economic participation in the global market (Government of South Africa: DET, 1996). Furthermore, the Tourism White Paper advocates the development and investment in an education system that will result in selfsufficiency and decrease reliance on imported skills (Government of South Africa: DEAT. 1996). In this way education will play a primary role in developing South African society's human resources. In lieu of the above-mentioned conditions, it is evident that introducing a sport tourism curriculum is beneficial as it contributes to developing a sustainable tourism industry in South Africa.

Sport has become a viable economic development strategy in the global sport community (Turco \& Eisenhart, 1998). This not only expands the traditional sportrelated jobs but also creates many new jobs related to sport, such as sport tourism. The Government of National Unity recognizes the importance of tourism as a major catalyst for development and job creation. and a growing generator of foreign exchange. South Africa wants to participate effectively in a rapidly changing national and global context. The development of a sport tourism curriculum to prepare individuals better to meet the demands and challenges of the contemporary tourism industry will be beneficial for South Africa.

Other significant benefits resulting from the development of a sport tourism curriculum include providing learning resources to supplement and support the development of sport tourism. linking adult education to current issues such as sport tourism. and promoting continuing education in the domain of sport tourism. 


\section{Additional Chapters}

Chapter II describes what is currently known about sport tourism and sport

tourism curricula. In Chapter III. Rhodes` Problem-Directed Instructional Design method as described in Byers and Rhodes (1998) is used to design a sport tourism curriculum.

Chapter IV summarizes the findings of the study. presents general conclusions about the curriculum as developed. and recommends areas for further research and study. 


\section{CHAPTER II}

\section{REVIEW OF LITERATURE \\ Curriculum Design}

Curriculum development and curriculum design are two terms that are often used interchangeably. Development has connotations of gradual evolution and growth whereas design may be defined as a deliberate process of devising, planning, and selecting the elements, techniques, and procedures that constitute some object or endeavor (Pratt, 1980). Morshead (1995) reports that curriculum design refers to the specific goals, content and organization of a curriculum. The term "curriculum design" will be used to refer to the operating principles that guide decision-making in practical situations.

The concept of curriculum design focuses on the ways in which curricula are produced, especially the actual arrangements of the components of the curriculum plan (Ornstein \& Hunkins, 1998). Giles, McCutchen and Zechiel (1942) note that the components of the curriculum plan include (a) objectives, (b) subject matter, (c) method and organization, and (d) evaluation. Posner and Rudnitsky (1990) contend that a systematic approach to developing curricula should be considered within the context of a theoretical perspective. Wiles (1999) notes that theory is required to design a plan of action. Eisner (1994) distinguishes between normative and descriptive theory in curriculum. 
The former is concerned with the justification of a set of values whereas the latter seeks to explain and predict events in curriculum without a concern for values. As education is value-laden, curriculum designers should be aware of the outcomes of their activities. A value, norm or criteria should be established in order to guide the process of curriculum development. An important factor in curriculum development is the questions of "how" to decide. Wiles (1999) notes that the principle for a decision is known as the "criteria" in curriculum work.

In order to represent an understanding or set of assumptions of how things work. curriculum designers use various paradigms and models. Although these models are not usually supported by research they are nevertheless valuable in explaining and preparing curricula (Wiles. 1999). Traditionally, curriculum development has been concerned with Tyler`s (1949) four fundamental questions as noted below:

1. What educational purposes should the school seek to attain?

2. What educational experiences can be provided to attain these purposes?

3. How can these educational experiences be effectively organized?

4. How can we determine whether these purposes are attained?

Curriculum designers refer to the above steps as the Tyler "cycle" to highlight the curriculum planning cycle of analyze, design. implement and evaluate. A noticeable feature of Tyler's questions is that they relate to Dewey's (1916) essentials of reflections. Dewey viewed reflective thinking as the means through which curriculum elements are unified. According to Dewey reflection is extended to social problem solving and not confined within specialized domains of knowledge (Tanner \& Tanner, 1995). In contrast 
to Tyler. Dewey repeatedly emphasized that aims derive from existing situations as opposed to being externally derived or imposed. Slattery (1995) reports that Tyler`s questions have dominated the study of curriculum over the past fifty years. Taba (1962) noted that most curriculum designs contain these four components. however many lack balance as the elements are poorly defined or are not considered in relation to a theoretical rationale. Similarly, Kelly (1999) asserts that the inadequacies of previous and current attempts at curriculum design can be attributed to the fact that they have not proceeded according to any overall rationale but in a piecemeal fashion. It is evident that the principles of curriculum have evolved as core procedures as opposed to theoretical guidelines (Wiles. 1999). Maccia (1965) refers to this as the "proxiological approach" to theorizing in contrast to a more theoretical or philosophical approach.

Tyler`s (1949) linear model of curriculum development has been criticized as being too simple (Kelly, 1999). He adds that Tyler's concern was with the purposes of the curriculum and is generally viewed as one of the founding fathers of the "aims-andobjectives" model of curriculum. As alluded to previously, if the function of identifying aims is interdependent with other functions in curriculum development. Tyler's linear model seems to be flawed as it does not reflect this required interdependence (Tanner \& Tanner, 1995). Giles, McCutchen, and Zeichel (1942) developed a more satisfactory model whereby Tyler`s four questions are represented as interdependent instead of linear. This schematic representation of curriculum development is shown in Figure 1. 


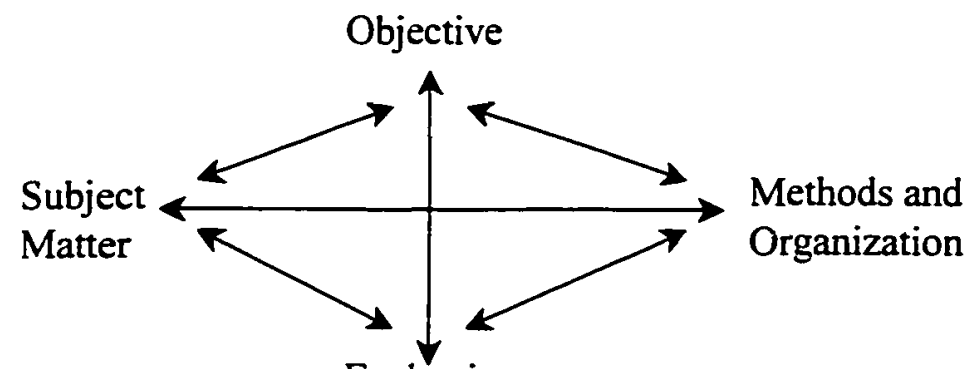

Evaluation

Figure 1. Interrelationship of Determinants in Curriculum Development

Note. From Exploring the Curriculum (p. 2), by H. H. Giles, S. P. McCutchen, and A. N.

Zeichel. New York: Harper Row. Copyright 1942 by Harper Row and Brothers.

Reprinted with permission. 
While essentially following Tyler's (1949) four questions, Taba (1962) further divided them into a seven-step sequence. and included the following:

Step 1: Diagnosis of needs

Step 2: Formulation of objectives

Step 3: Selection of content

Step 4: Organization of content

Step 5: Selection of learning experiences

Step 6: Organization of learning experiences

Step 7: Determinants of what to evaluate and of the ways and means of doing it.

Giles. McCutchen. and Zeichel's model and Taba's model are criticized on the same basis as Tyler's model. The four functions in curriculum development are interdependent functions as opposed to inflexible sequential steps. Although the former model reflects interdependence, it does not illustrate the bases on which decisions regarding these functions are made (Tanner \& Tanner. 1995). In other words. if there is any starting point to curriculum development. it derives of the educational situation already in existence and should be directed at the analysis of the problems arising from that situation. Tanner and Tanner note that Tyler recognized that the objectives themselves are a matter of choice, and should hence be considered value judgments. However in recent years this aims-and-objectives approach tends to be value-neutral and purposely avoids the issue of deciding what kinds of instructional task and corresponding activities are deemed educational (Kelly, 1999). The aims-and-objectives approach to 
curriculum development has not been limited to school curriculum development but has also been used for curriculum development in higher education.

A more recent approach to curriculum development has emerged with the emphasis on the organization of educational experiences. Stenhouse (1975) describes this model as a "process" model and Blenkin and Kelly (1987) as a "developmental" model. According to this model, the curriculum designer starts from a concept of education as a series of developmental processes that the curriculum should be designed to promote (Kelly, 1999). He adds that this design is based on the underlying principle that the primary concern of the educational process is with human development. and that this development should be envisaged within a democratic social context.

It is evident that curriculum components can be organized in various ways. Most curriculum designs are modifications and integrations of three basic design types: (a) subject-centered designs, (b) learner-centered designs, and (c) problem-centered designs (Omstein \& Hunkins. 1998). The core aspects of these three designs will be highlighted below:

\section{Subject-Centered Designs}

Subject-centered designs are considered to be the most popular and widely used design. This stems from the strong emphasis that has been traditionally placed upon content in our schools. Typical subject-centered designs include subject design. discipline design, broad fields design. correlation design, and process design (Ornstein \& Hunkins, 1998). While it is beyond the scope of this chapter to expand on each design 
separately, suffice it to conclude that all these design stress the importance of subject matter.

\section{Learner-Centered Designs}

Learner-centered designs focus on the student as opposed to subject matter. Ornstein and Hunkins (1998) note that variations of this design include child-centered designs, experience-centered designs, radical designs and humanistic designs. Proponents of these designs emphasize the learner's experiences when developing curriculum.

\section{Problem-Centered Designs}

Problems of living, for both the individual and society in general, are at the core of problem-centered designs. As problem-centered designs represent social problems and the interests and abilities of the learners, various designs exist (Ornstein \& Hunkins. 1998). They include life-situations design. core design. social problems and reconstructionist designs.

It is contended that these designs are limited as they load on a specific component of the curriculum. Moreover. it is apparent that each of the models that have been identified represents a distinctive conceptualization of curriculum as well as an equally unique concept of what the purposes and functions of education are.

\section{Design Dimension Considerations}

The components of a curriculum can be viewed along several dimensions. These dimensions include (a) scope, (b) integration, (c) sequence, (d) continuity, (e) 
articulation. and (f) balance (Omstein \& Hunkins. 1998). Each of these dimensions will be mentioned below.

\section{$\underline{\text { Scope }}$}

The breadth and depth of the curriculum content is generally referred to as its scope. Tyler (1949) regarded scope as including all the content, topics. learning experiences. and organizing threads encompassing the education plan. The challenge of determining what knowledge is of most worth becomes a significant question when deciding upon the scope of the curriculum. It also forces curriculum decision-makers to reflect on the philosophical foundations of the curriculum (Ornstein \& Hunkins. 1998).

\section{Integration}

When dealing with scope, a major challenge is the linking of all types of knowledge and experience within the curriculum plan. This linking of activities is referred to as integration. Ornstein and Hunkins (1998) report that it stresses horizontal relations among various content topics and themes encompassing all domains of knowledge recognized. They add that integration allows the learners to obtain a unified view of knowledge. Moreover, Taba (1962) asserted that integration was also an attempt to interrelate the content components with learning experiences and activities that would facilitate learning.

\section{Sequence}

In order for the curriculum to encourage cumulative and continuous learning. attention is paid to the vertical relationship of the curricular elements (Ornstein \& Hunkins, 1998). They add that a controversial issue regarding sequence is whether it 
should be based on the logic of the subject matter or on the way in which individuals process knowledge. While one cannot neglect the logic of content. it is also important to recognize that learners have individual and group interests and these concerns should be addressed. Smith, Stanley and Shores' (1957) four principles for sequencing content include (a) simple to complex learning, (b) prerequisite learning. (c) whole to part learning, and (d) chronological learning. Posner and Strike (1976) have developed the following four principles for determining sequence: (a) concept-related, (b) inquiryrelated, (c) learning-related, and (d) utilization-related learning.

Tanner and Tanner (1995) note that as teachers are the products of disciplinecentered universities, they generally seem to ignore the requirements for curriculum synthesis on both the vertical and horizontal planes. As a result. the scope of each course is likely to be restricted to only a segment of the discipline or subject field of which it is a part. Moreover. Tanner and Tanner add that the sequence of courses within a discipline or subject field are inclined to be arranged in a linear fashion irrespective if the sequence is sound.

\section{Articulation}

The inter-relatedness of various aspects of the curriculum is referred to as articulation, and can be either vertical or horizontal (Omstein \& Hunkins, 1998). Please refer to Figure 2 which illustrates these relationships. 


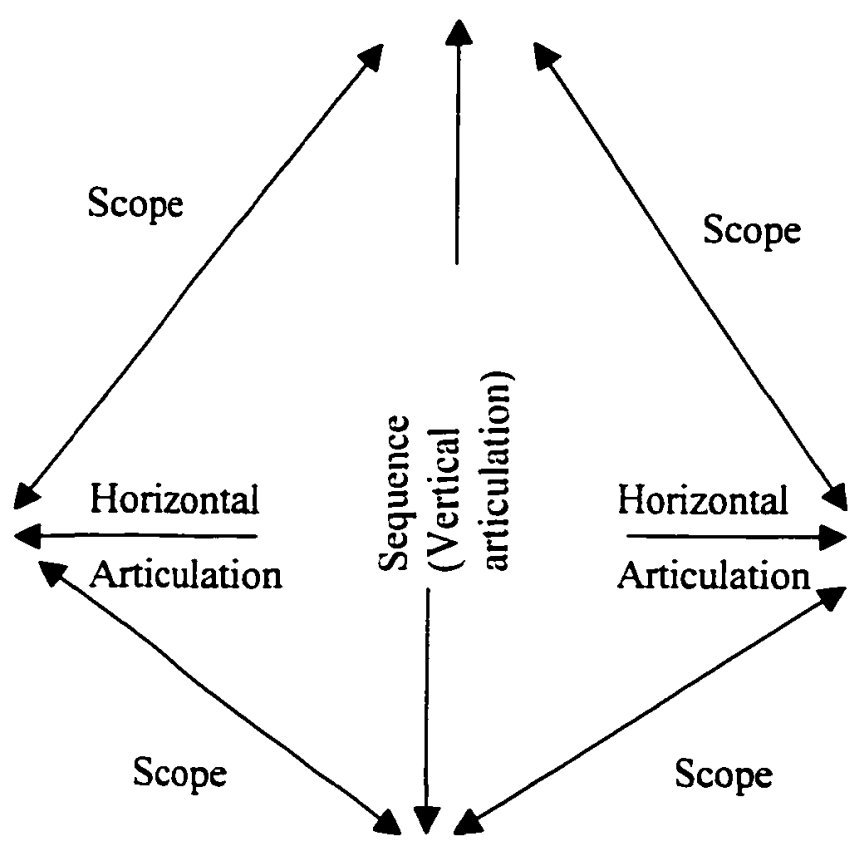

Figure 2. Curriculum Articulation

Note. From Curriculum development: Theorv into practice $\left(3^{\text {rd }}\right.$ ed.) (p.

22), by D. Tanner and L. Tanner, 1995, New Jersey: Prentice Hall. Copyright 1995 by Prentice Hall, Inc. Adapted with permission. 
Balance

Balance refers to the concern that appropriate weight is given to each aspect of the design in order to prevent distortions. Similarly, Tanner and Tanner (1995) identify balance as to the degree to which the curriculum is in harmonious proportion. It is argued that curriculum should be balanced in terms of subject matter and learner (Ornstein \& Hunkins. 1998).

\section{Continuity}

Continuity refers to the vertical manipulation or repetition of curriculum components (Ornstein \& Hunkins. 1998). When curriculum designers feel students should have increased depth and breadth of knowledge over the length of curriculum. major ideas and skills are reintroduced on the basis of continuity. This increasing depth and breadth is given prominence in the Deweyan concept of the "spiral curriculum". In later years Bruner (1960) also promoted the idea of a spiral curriculum. Whereas Dewey`s spiral curriculum recognizes the learners' experience as the starting point. Bruner's spiral curriculum takes it starting point from each separate discipline as envisaged by the discipline specialists.

\section{Sport Tourism Curricula}

Sport tourism has been progressing favourably worldwide as an academic discipline. The University of Luton who have instituted a sport tourism degree program in recent years notes that the sport tourism industry has recognized the importance of quality management throughout its operations and sectors. (University of Luton, 1998). 
Sport tourism programs are also being implemented at post secondary institutions in the USA, Europe and Australia (Swart. 1999b). Gammon and Robinson (1999) note that a number of factors require consideration in the development and design of the broadly defined elements of the sport tourism curriculum. They further report that it is essential to notify would-be developers and designers on issues concerning the nature and evolution of the sport tourism curriculum. This will more than likely stimulate debate concerning the core curriculum, design and development of this new and emerging field (Gammon \& Robinson, 1999).

An understanding of sport tourism is essential to the development and design of a sport tourism curriculum. In order to identify the components of a sport tourism curriculum. it will be beneficial to understand what is meant by sport tourism in order for the curriculum to meet the future requirements of the sport tourism industry.

Gammon and Robinson's (1999) case study illustrates the development and design of the first undergraduate curriculum in the UK specifically dedicated to sport tourism. The BA (Honours) sport tourism degree was introduced at the University of Luton in 1998. Gammon and Robinson note that sport tourism as a recognized qualification has no precedence in the UK; consequently knowledge and expertise were sought from various international institutions including the Sport Tourism International Council (STIC) which ran a number of related courses. A significant question related to the historical elements is "what should a sport tourism degree consist of?" (Gammon \& Robinson. 1999). They further argued that is it necessary to first determine what is meant by sport tourism. Consequently. one of the main discussions to arise was whether to use 
the term sport or sports. This issue is of central importance to the overall rationale and structure of the course. Presently, in the literature sport tourism and sports tourism are being used interchangeably (Gammon \& Robinson. 1999). However, as alluded to in Chapter I. sports suggests a collection of separate activities whereas sport is a collective noun that includes all activities that meet the standards. Gammon and Robinson contend that sport tourism is a considerably broader concept that embraces sport as being both recreational and competitive, and institutionalized and transitory. In contrast, sports tourism is limited as it focuses upon competitive sporting travel. Definitions of sport tourism as provided by a number of authors such as Kurtzman and Zauhar (1997) and Delpy (1998) suggest that sport tourism entails the study of the predetermined or incidental participation or attendance of sports based activities, by individuals or groups outside their home environment (Gammon \& Robinson, 1999). They add that it was in this broad framework that the undergraduate program at Luton was structured.

In terms of curriculum analysis, Gammon and Robinson (1999) found a number of specific factors responsible for developing a BA (Hons) in sport tourism. They further highlight that their discussion is from a UK perspective and that only key external elements were identified. These elements include institutional and departmental factors. and market factors. In terms of institutional factors, Gammon and Robinson note that the Department of Tourism and Leisure resides within the business school at the University of Luton, and consequently must adhere to the common business cores which are a component of every undergraduate course in the school. They add that the department in which the course is delivered has a critical role to play in the final format of the program. 
Concerning market factors. Gammon and Robinson contend that little research has been undertaken that identifies a market for such a course, though initial investigations assisted in developing a number of points within the University of Luton's validation document. A key point concerns the immense growth in this domain over the last ten years that has left educational institutions lagging behind in meeting the requirements of industry. These requirements include the provision of trained graduates who understand the consumer from a trained sports perspective and with the ability to manage the needs of the tourist.

Gammon and Robinson (1999) conclude that a core body of knowledge in sport tourism is still some way from being developed. They further contend tourism professionals and sport studies academics are still contesting the content and coverage of their own fields let alone the specialist sport tourism domain. Gammon and Robinson assert that the key is identifying core aspects of sport tourism and synthesizing these within the local context of operation. Moreover, they contend the diversified nature of these programs should be developed within a consistent framework that will enhance the identity and meaning of the subject.

Given the limited research concerning sport tourism curricula, a study was conducted to determine the scope of sport tourism courses, modules, programs or degrees that are currently being offered by academic institutions (Swart, 1999b).

A descriptive research design incorporating the survey method was used for the purposes of investigating institutions offering sport tourism subject matter within their curriculum. Respondents were asked to answer a number of questions concerning the 
type of sport tourism academic offerings, the academic departments providing the content. the course titles. and number of courses. Respondents were asked to briefly describe the curricular rationale. aims and objectives of their course offerings. The survey was conducted by placing the questions over four specialized list-servs on the Internet. The members of each list represent academic staff specializing in one or more of the following disciplines: leisure, recreation. sport management. sport. tourism management. hospitality. physical education. and sport tourism (Swart. 1999b). The survey was conducted over a period of three weeks in September and October 1999 with a follow-up in October 1999.

The results of the study were analyzed to identify the geographical location of the institutions, the type of sport tourism academic offerings, the academic departments providing the content. the course titles which offer sport tourism content. the number of courses. and the date when these courses were instituted. In addition. core aspects of sport tourism offerings will be further identified. The curricular rationale, aims and objectives of these course offerings were also content analyzed.

Of the twenty-eight responses to the survey, only twenty-four were usable. The main geographical location of the institutions was the USA. Other countries represented in the sample include Belgium, Canada. United Kingdom. Australia, and South Korea.

\section{Type of Academic Programs}

Forty-two percent of the respondents stated their institution offered sport tourism content. The most prevalent type of sport tourism academic offerings was in the form of modules within other courses $(78 \%)$, followed by course offerings $(56 \%)$ and sport 
tourism degrees (40\%). Sport tourism courses were offered as early as 1979 at one institution. However, more focused attention on sport tourism. in the form of courses and degrees is more recent. These courses and degrees were instituted during the period 19961999.

\section{Degrees or Certificates Offered}

Sport tourism degrees were offered at a graduate and undergraduate level. They included Associate Degree of Sport Tourism Management. Bachelor of Sport Tourism Management. Bachelor of Sport Tourism Management (Hons) and BA (Hons) Sport Tourism. Additionally, Associate, Bachelor. Master and Doctorate Degrees in Sport Tourism Management were offered. as well as Business Administration degrees at the Associate, Bachelors, Masters and Doctorate level with specialization in sport tourism. A certification program was also offered whereby graduates earn the designation of "Certified Sport Tourism Manager". TAFE (Vocational Education and Training) and certificates and diplomas are also available specific to the ski industry. for example Diploma of Tourism (Snow Sports Management) and Diploma of Tourism (Outdoor Recreation).

\section{Academic Departments}

Academic departments providing sport tourism content included the following:

1. Physical Education

2. Physical Education \& Recreation

3. Physical Recreation

4. Sport Management 
5. Tourism (Ski Industry Programs)

6. Tourism \& Hospitality Management

7. Tourism \& Leisure

8. Tourism Management

9. Recreation. Parks \& Tourism

10. Tourism. Convention \& Event Management

\section{Course Titles}

Course titles of these sport tourism offerings include the following:

1. Recreation courses

2. Management courses

3. Tourism courses

4. Sports tourism foundation courses

5. Sports tourism management courses

6. Sports tourism law courses

7. Sports tourism finance courses

8. Sports tourism specialization courses

9. Sports tourism projects and dissertation courses

Course Title Analysis

A further breakdown of these courses are listed as follows: 
$\underline{\text { Recreation courses. }}$

Outdoor Recreation (2)

Management courses.

Public Relations

Environmental Impacts

Human Resource Management (2)

Facility Planning \& Design

Sponsorship

Tourism courses.

Principles of Tourism

Issues in Tourism Development

Tourism \& Hospitality Studies

Guest Host Interdependency \& Image Development

Followers Abroad

Information Systems in Tourism Environment

Sport tourism foundation courses.

Sport Tourism (2)

Foundations of Sport Tourism

Introduction to Sport Tourism

Sport Tourism Relationships

Sport Tourism Studies

Issues in Sport Tourism (2) 
The Sport Tourism Industry

Historical Perspectives of Sports Tourism

Societal Impacts of Sport Tourism

Sport tourism management courses.

i. General sport tourism management

Economics of Sport Tourism (2)

Decision Making in Sport Tourism Management

Programming in Sport Tourism

ii. Planning and operations of sport tourism

Sport \& Tourism Policy \& Planning

Management Perspectives in Sport Tourism

Project Management in Sport Tourism

Quality Control in Sport Tourism Enterprises (2)

Operational Techniques for Sport Tourism Enterprises

Strategic Planning \& Operation of Sport Tourism Organizations

Management of Sport Touristic Endeavor

iii. Marketing of sport tourism

Sport \& Tourism Marketing (2)

Marketing of Sport Tourism Activities

Strategic Marketing in Sport Tourism

Lifestyle Marketing in Sport Tourism

Public Relations \& Promotion of Sport Tourism Activities 
$\underline{\text { Sport tourism law courses. }}$

Sport \& Tourism Law

Legislation \& Taxation impacting Sport Tourism

Personnel Management \& Labor Laws affecting Sport Tourism

Liability, Insurance \& Safety in Sport Tourism

Sport tourism finance courses.

Financial Management (2)

Investment Analysis \& Financial Management

Financial Accounting for Sport Tourism

Managerial Accounting in Sport Tourism Enterprises

Financial Policy in Sport Tourism

Specialization courses.

i. International sport

Sporting Cities

International Sport Tourism (2)

International Visitation in Sport Tourism

Futuristics in International Sport Tourism

ii. Organizational environment of sport tourism

Media Intervention for Sport Tourism

Media \& the International Olympic Movement

Entrepreneuralism in Sport Tourism (2)

Franchising. Sponsoring \& Concessions for Sport Tourism Enterprises 
Role of the Computer in Sport Tourism Endeavors (2)

Volunteer Culture in Sport Tourism

iii. Winter sport tourism

Snow Sports Management

Ski Area Management

Ski Facilities Management

Alpine Resort Management

iv. Sport tourism events

Management of Events

Venue \& Event Management (2)

Event \& Stadia Management

Management of Sports

Sport tourism projects and dissertation.

Special Project in Sport Tourism

Dissertation in Area of Sport Tourism Specialization (6)

\section{$\underline{\text { Rationale. Aims and Objectives }}$}

The study indicated that a total of 84 sport tourism courses are currently being offered at academic institutions. with $82 \%$ of the courses being offered by sport tourism degree-granting institutions. The institutions reported that the curricular rationale. aims and objectives of these courses were as follows. 
Introduction to Sport Tourism

- To introduce students to the field of sport tourism by means of a practical course.

- Survey courses with sport tourism being one of the areas surveyed.

- In years one and two. the common route-specific core constitutes a high proportion of the curriculum and reflects the need to provide the broad foundation knowledge and skills which are required by the sport tourism manager.

- To provide students with a broad base understanding of sport tourism. to understand the different types, and to become aware of the diverse opportunities that exist in the field of sport tourism.

Preparation for the Sport Tourism Industry

- Sport tourism is progressing encouragingly as an academic discipline and the industry has increasingly recognized the necessity for quality management. professional career structures and better retention rates throughout its operations and sectors.

- To provide students with the knowledge and skills required of managers in the Australian and international sport tourism industry.

- To address all aspects of the profession by presenting both the theoretical foundations and application of these principles.

- To train employees for employment within alpine resorts in Australia and overseas. 
- The general aim of the BA (Hons) Sport Tourism program is to provide a broad education to first degree honors level. developing the knowledge and competencies required for employment and career development in sport tourism within the public and private sectors.

- Also for UK and overseas students dealing with an international clientele and in many cases with multinational employers. These include organizational and managerial abilities specific to the sport tourism industry, together with transferable competencies in personal effectiveness, communication and numeracy. a holistic approach to the analysis and solution of problems. and an understanding of business in the broader sense as well as in the sport tourism context. The course provides a base for students wishing to enter any sector of the sport tourism industry.

- The program aims to give an adequate science and practical base for study of sport tourism operations and preparation for a career in the industry.

- The program is a combination of both theoretical knowledge and practical experience in sport tourism management. Overall, the academic programs provide managers with an educational experience that will permit them to improve on-the-job performance.

- To provide a broad learning experience for the personal and professional development of management personnel in the sport tourism industry.

- To provide an organized program of study that would allow courses and qualifications to be kept current and relevant within the sport tourism industry. 


\section{Educational Processes}

Eighty nine percent of the institutions offer sport tourism courses or modules via the classroom setting. Classroom methods included lecture, seminar, research as well as practical experiences. Distance education was cited in $10 \%$ of the cases. with the Internet being the primary learning modality. One of the three institutions offering sport tourism degrees is offered entirely by distance education. One institution offering courses in the classroom indicated that they would be offering these courses by distance within three years. It is interesting to note that this institution has recently introduced sport tourism as a degree offering.

\section{Future Courses or Programs}

Fifty percent of those institutions not offering sport tourism in the curriculum indicated that they envision a need, and have plans to develop curricular offerings in sport tourism. Thirty-three percent indicated that there may be a possibility to develop curricular offerings in sport tourism, whereas $17 \%$ reported that they do not have plans to develop curricular offerings in sport tourism. Some institutions recognized the importance of sport tourism but cited the main reasons for not offering sport tourism curricular were faculty size and workloads, and budgetary constraints.

\section{Survey Summary}

Although only $40 \%$ of the respondents indicated sport tourism content within their field of endeavor. there has been an increasing focus on sport tourism as an academic discipline in recent years. This focus is being experienced worldwide, with sport tourism curricular offerings on four continents. This interest is also reflected in the 
burgeoning degree and diploma certifications in sport tourism. with degrees being offered by institutions on three continents. The diverse range of academic departments providing sport tourism content further indicates the growth of sport tourism curricular offerings within educational institutions. Moreover. it suggests that there is an opportunity for joint programs in sport tourism. particularly for institutions that are limited by faculty numbers and budgetary constraints.

The course titles indicate that there is a wide range of areas within the sport tourism industry. Students have the opportunity to gain the necessary foundational knowledge and skills, while being able to focus on a particular area of specialization. Some programs are highly specialized such as the tourism diploma program specific to the ski industry, among others. The course titles further indicate that there is a strong link to the management discipline.

Overall, the curricular rationale, aims and objectives of the sport tourism degree programs and courses are to introduce students to the field of sport tourism. and to prepare them adequately for performance in the sport tourism profession. The institutions recognize the growth of sport tourism in recent years, and the necessity to prepare students for a career in the sport tourism industry.

The recognition of the importance of sport tourism is reflected by the growing number of institutions who envision a need. and have plans to develop sport tourism curricular offerings in the future. As alluded to previously. one of the main reasons restricting institutions from offering sport tourism curricula is the limited faculty numbers, and budgetary constraints. 
This study illustrated the extent to which sport tourism has developed as an academic discipline. There is an increasing international interest and recognition of sport tourism as a niche market. Institutions are offering courses and degrees to meet the requirements of this new industry. The study has contributed to the debate concerning the ccre aspects of a sport tourism curriculum, and the nature of sport tourism curriculum. The study indicated that core aspects include foundational courses, with a strong management perspective. However. a wide variety of options are available within the industry, allowing students to specialize within a particular area.

Analysis of Sport Tourism Curricula with Respect to Curricular Components In terms of the analysis of sport tourism curricula with respect to curricular components of scope and sequence, the following observations can be made. The scope of sport tourism curricula is diverse and is influenced by various factors such as institutional, departmental and other external factors. Both sport tourism degrees in the United Kingdom and Australia are specific to these contexts. Moreover. all sport tourism programs and degrees were strongly influenced by market-related factors in order to meet the requirements of this new industry, namely sport tourism. It is evident that determining what knowledge is most worth becomes a significant question when deciding upon the scope of the sport tourism curriculum.

Concerning the sequence of the sport tourism curricula described above, it is apparent that prerequisite learning and simple to complex learning is given prominence throughout the curricula. The three degree programs start with foundational courses and then proceed to various areas of specialization. As universities tend to be discipline- 
centered. the design-type utilized in design all the curricula described seems to be subject-centered. Moreover, the sequence of courses appears to be arranged in a linear fashion, even though this may not be the most appropriate sequence. Although both the sport tourism curricular implemented in the United Kingdom and Australia is specific to their particular cultural context. they both appear to be designed according to the "conventional" approach that draws upon applied psychology and educational craft wisdom for prescribing solutions to education problems. Gammon and Robinson (1999) noted that knowledge and expertise were sought from various international institutions. An element of the "marketing" approach was also apparent as the curricula were based upon the perceptions of what the sport tourism industry wants or needs. The author contends that current sport tourism curricular offerings are deficient to meet the future requirements of the sport tourism industry within South Africa. It is necessary to design and implement a curriculum that will allow sport tourism professionals to resolve the performance problems within South Africa's sport tourism industry. This will determine the scope of the sport tourism curriculum, as this knowledge will be considered most worth. The most appropriate sequence that will give balance to the curriculum will be identified. Thus a curriculum design appropriate for the next decade of sport tourism in South Africa is envisioned.

\section{Curriculum Design for the Next Decade}

It is contended that problem-directed design or enterprise-directed design would be most suitable to design the sport tourism curriculum. The "model" or "conception" of 
instructional design that will be utilized to develop the sport tourism curriculum is Problem-Directed Instructional Design (Byers \& Rhodes, 1998). Although it is essentially an instructional design model. this approach is favored as an alternative to conventional curriculum design models. The generic design is problem or solution oriented. According to this conception of instructional design. as identified by Byers and Rhodes, the design of instruction is regarded as a systematic process by which a series of problems in the design context are identified. defined and resolved. When instructional design is viewed in this way, the designer is not limited to any specific psychological. sociological. methodological. or pedagogical constructs, but is free to use and apply all appropriate constructs suitable to the context within which the instructional problem has been identified (Tennis, 1991).

There are three broad approaches to instructional design (Gentry, 1991). The first of these is the "conventional" approach, as described earlier. that draws upon applied psychology and educational craft wisdom for prescribing solutions to educational problems. Moreover. conventional design has a technical orientation and employs a systems approach. The conventional design process is generally linear with a series of steps to be followed in the creation of the instructional design.

The second methodology is referred to as the "marketing" approach as it is driven by the perceptions of clients (in this case, students) of what they need or want. This method focuses on the consumer. Market research, audience analysis, and predictable ways of eliciting consumer satisfaction are the basis for decisions during the design phase (Rhodes, 1990). Needs assessment is a process that is commonly representative of a 
merchandising conception. finding out what potential participants perceive as personal or group needs.

Byers and Rhodes' (1998) generic approach is the third approach to instructional design. As mentioned previously, its components are conceptually distinct but the design process is recursive. It allows for unlimited iterations throughout the procedure. This approach has been selected as the instructional design to be employed. The conventional and marketing approaches generally employ time-tested formulas to arrive at solutions to pedagogical problems. These approaches are limited in terms of the facets of the initial design situation considered and the array of possible solutions they can provide (Franson. 1996). The generic model is not as restrictive as it considers a wide array of contextual input variables and allows the problem. instead of any one accepted approach to problem solving. to guide design efforts. The designer has greater scope, and the probability of finding the best solution to the problem is greatly enhanced (Gentry, 1991). It is contended that the use of Byers and Rhodes' instructional design model is justified as a comprehensive design model, even though it has an instructional orientation. A problemsolving focus is required as sport tourism studies is a complex curriculum and instructional process, with many critical elements and performance problems. Moreover. as the design is specific to the context for which it is intended, no assumptions about the transfer of curriculum and instructional designs from one cultural context to another will be made. 


\section{CHAPTER III \\ SPORT TOURISM CURRICULUM DESIGN}

The sport tourism curriculum will be designed using the methodology of Problem-directed Instructional Design as outlined in Chapter II. As such. Byers and Rhodes` (1998) Problem-Directed Instructional Design utilizes the principles of design that are employed by other professions such as engineering and architecture. As indicated in Chapter II, even though this is essentially an instructional design model. this approach is favored as an alternative to conventional curriculum design models (i.e., applied psychology and educational craft wisdom). According to this conception of instructional design, the design of instruction is regarded as a systematic process by which a series of problems in the design context are identified, defined and resolved (Byers \& Rhodes, 1998). In other words, as described by Tanner (1991) previously, the designer is free to use and apply all appropriate constructs suitable to the context within which the instructional problem has been identified and is not limited to any specific psychological. sociological. methodological or pedagogical constructs.

The generic design is problem or solution oriented. The five principal components of Problem-Directed Design are (a) preparation, (b) formulation, (c) execution, (d) review, and (e) revision. Preparation for the design requires identification of the design context, reasons for undertaking the design. and identifying significant 
features in the design context. It also includes identifying performance problems in the design context. types of performance problem. the specific education or training problem to be resolved. the instructional problem to be resolved. and the type of instructional problem to be resolved.

The formulation phase includes defining the instructional design problem to be resolved, identifying ways to resolve the problem. devising alternative resolutions for each instructional design problem. assessing the alternative resolutions for each design problem. and selecting the most suitable resolution for each design problem.

The execution phase includes realizing the new or revised design. and illustrating the resolution to the instructional problem. The review phase requires the assessment of the new or revised design, and the interpretation of the assessment results. Finally, in the revision phase. the design is altered. reviewed and revised. It is important to note that an information search is carried out during each step in the design process. Although the components are conceptually distinct, the design process is recursive.

The stages to be followed in designing the educational experience will consist of the five components of this method described above. The preparation phase of the instructional design model will be used to answer research questions four and five. that is to identify the particular clientele, and specific context for the sport tourism curriculum. respectively. The formulation phase of the instructional design model will be used to identify the specific content for the sport tourism curriculum, thereby addressing research question six. The execution phase will be utilized to determine the scope (research question seven), sequence (research question eight) and the delivery system (research 
question eight) of the sport tourism curriculum. The review phase will be used to assess the scope and the sequence of the sport tourism curriculum. The relative importance of each stage, and the principal difficulties with each stage will be identified.

\section{Preparation \\ $\underline{\text { Performance Problem }}$}

There are many performance problems within the sport tourism industry in South Africa. Major sport events have been identified as the most obvious areas of the sporttourism link (Weed \& Bull. 1997). This author contends that it has created a misperception of sport tourism in South Africa. Upon viewing the various sport and tourism policy documents below, the misperception of sport tourism becomes apparent. This misperception is one of the main reasons why South Africa's sport tourism potential is not being realized. It is necessary to have a holistic understanding of sport tourism in order to enhance the overall performance of the sport tourism industry. Government Policy Papers on Sport and Recreation

Due to a lack of understanding of the overall impact of sport on society, the White Paper of the Government of South Africa Department of Sport and Recreation [DSR] (1996) outlines the relationship between sport and recreation, and other sectors such as health, education, economy, crime, nation building, and international relations. It is interesting note that tourism, as a sector, is not explicitly mentioned. Overall. the document makes no reference to tourism directly or indirectly. 
Due to the general lack of understanding in South Africa regarding the role played by sport and recreation, the DSR recognized the necessity of including a synopsis of the role of sport and recreation with its 1996 budget speech (SISA, 1996). In this document the link between sport and tourism is unequivocally stated. Note - Emphasis has been added to the terms "sport" and "tourism" in the sections below.) The following extracts as provided by SISA demonstrate the relationship between sport and tourism:

- Whether talking about drug abuse, national health, reconciliation and nationbuilding, trade and industry. tourism and job creation. consolidation and establishment of international relations, restoration of the culture of learning and teaching or reintegration of the so-called marginalized youth into the mainstream of our society, there is absolutely no way one can even unconsciously diminish the centrality of sport in addressing these matters.

- Research has demonstrated the economic benefits of hosting sporting events. especially in the areas of tourism, job creation and facility development.

- Sport's role in boosting tourism throughout the world is well known. The influx of sports fans to sports venues has a spin-off to other forms of tourism and in this way benefits all sectors of the population. The international nature of top sport results in a symbiosis between sport and tourism. Because the financial spin-off from the surge in international tourism flows through the economy, it ends up boosting profits for the companies directly involved in the tourism industry. 
- The 1995 Rugby World Cup Tournament contributed significant financial benefits to the South African economy. The direct spending by the approximately 20000 foreign tourists in South Africa on accommodation. transport and food during the period of the tournament was about $\mathrm{R} 175$ million (US\$29 million). (p. 4)

While the White Paper of the Department of Sport and Recreation provides national guidelines for sport and recreation in South Africa, the Rainbow Paper. 'Let's Play and Develop” provides a framework for the promotion and development of sport and recreation by the Provincial Department of Sport and Recreation in the Western Cape (DSR: Western Cape. 1995). Similar to the priorities established in the White Paper, the Rainbow Paper recognizes that sport and recreation can contribute to the development of human resources. The six main policy principles of this document are:

Development should be demand driven.

Development should be community based.

Sport and Recreation is a human right.

"Some for all" rather than "All for some".

Integrated Development.

Environment Integrity.

While there is no specific linkage to tourism in this document, cognizance should be taken of the following policy objective. "make the Western Cape the 'Sports Mecca' of South Africa and Africa via the hosting of major sports events in this province" (DSR Western Cape, 1995, p. 5). In keeping with this objective, the DSR: Western Cape 
Strategic Business Plan for 1999/2000 intimates that the directorate plays an important role in the hosting of major sport and recreation events in the province. Moreover. "the objective of hosting these events is to attract and develop a sport tourism base for the province" (DSR: Western Cape, 1999, p. 2).

While the sport tourism relationship is increasingly evident in sport policy documents in South Africa, it is apparent that major sporting events are the focus of this linkage. It is contended that this limited perception of the sport tourism connection negatively impacts the development of the sport tourism industry in South Africa. Government Policy Papers on Tourism Development and Promotion

In terms of tourism potential the White Paper "Development and Promotion of Tourism in South Africa" (1996) notes the following:

In addition. unique archaeological sites and battlefields. the availability of excellent conference and exhibition facilities, a wide range of sporting facilities. good communication and medical services, internationally known attractions and unrivalled opportunities to visit other regionally internationally known attractions make South Africa an almost complete tourist destination. (p. 1)

The White Paper (1996) further notes that "investment and casino licenses should be focused on what additional advantages relating to tourism infrastructure (hotel. conference facilities, sport and other recreation facilities) could be created through the proposed development" (p. 37).

The Tourism White Paper identified the absence of clear product branding and an innovative marketing strategy as a key weakness in the current tourism sector 
(Government of South Africa: DEAT, 1996). It further recommended that the traditionally geographically driven promotional campaigns be abandoned in favor of a segmented theme-based approach. Consequently, a number of themes. including sport tourism. have been identified by the Government of South Africa: DEAT (1996) as potential promotion campaign foundations as illustrated below:

- Emphasize the development of products that offer good potential for development. for example cruise tourism, Afro-tourism. sports tourism. cultural forms of tourism. ecotourism. conference and incentive travel. wildlife safaris, hunting and others

- Encourage the development of sports tourism and encourage the provision of facilities. training, marketing and promotion to give emphasis to the development of this segment of the industry. (p. 40)

Similarly, in terms of international marketing. it is recognized that national and provincial tourism organizations should agree on a coordinated and effective marketing strategy. Moreover, key tourism stakeholders in South Africa assert "this may not imply the promotion of separate brand identities by provinces but possibly a number of strong product lines (e.g.. ecotourism, culture tourism. sports tourism) which are applicable across provincial boundaries" (Government of South Africa: DEAT, 1996, p. 50).

Concerning youth development. the White Paper identifies the necessity for programs aimed at addressing the needs of the youth. especially to address backlogs in training, job creation and recreation. Such programs include "support and promote 
capacity building programs for youth involvement in the tourism industry, particularly in areas such as sport" (Government of South Africa: DEAT, 1996, p. 46).

An analysis of the Tourism White Paper reveals that a very strong relationship exists between sport and tourism. Key aspects highlighted include tourism potential. investment opportunities. marketing strategies and youth development. While sport tourism is identified as a product brand, the White Paper does not state what sport tourism entails. However. upon reviewing the sports tourism promotional campaign. South Africa Sports Tourism. the emphasis given to sport events becomes clear. This campaign will be examined later in this chapter.

The Western Cape Tourism Green Paper provides the policy foundations and competitive strategy for the Western Cape to become a leading global tourism destination (Western Cape Department of Economic Affairs, Agriculture and Tourism. 1999). In highlighting the strengths and opportunities of the province, this department notes that various opportunities have not been fully explored. and include the following:

- Establishing the Western Cape as a global meeting. incentive. event. exhibition and convention destination.

- Expanding and promoting our cultural assets and experiences.

- Improving our entertainment opportunities.

- Capitalizing on our potential as a premier environmental and outdoor destination. The Western Cape is already well established as an environmental and outdoor paradise. Capitalizing on the global trend towards 
niche experiences (adventure travel, sport tourism, hiking, environmental interests and environmental sensitivity) could further enhance this image.

- Developing our conservation assets to the advantage of tourism. (p. 2)

The following target markets have been identified in the Western Cape Department of Economics Affairs. Agriculture and Tourism Green Paper (1999):

- Experiencers - Want an introductory overview and fairly superficial experience of the destination and its main attraction within a limited time period. These include the Iconeers, Sightseers, Socializers, Ecotourists and VFRs (visiting, friends, and relatives).

- Explorers - Want to have an intensive experience, travel to lesser-known areas, and risk more. Sub-segments include Backpackers, Trailers. Adventurers, Heritage Hunters, and Special Interest niches.

- Entertainers - Want to relax in a limited action. entertaining environment. Sub-segments are Sun and Surfers. Shoppers. Food and Winers, Music and Theatre fans, Romantics, and Night Lifers/Ravers.

- Engagers - Primary reason for visit is to meet a particular party/parties to build relationships, exchange common ideas and conduct business. They include Business Travelers, Officials, Politicians and Academics.

- Eventers - Visit area to partake in an organized event. These include Sport Lovers (participants in or spectators at sport events), Culture Lovers, Festival Goers and Conventioneers. (p. 35) 
It is further noted that the "explorers" and "eventers" should be targeted as the most important new growth segments. In order to develop our resources. the Green Paper advocates that the following programs should be initiated:

- A heritage tourism program. including the identification and development of historical, cultural, and socio-political assets, arts. crafts, music and social interaction.

- An ecotourism program aimed at developing the many unexplored conservation areas and parks in the province.

- An adventure tourism program. including the development of a trails network (hiking. biking. $4 \times 4$. horseback) and other adventure tourism opportunities.

- An events tourism program aimed at increasing the number and extent of sport and cultural events. conventions and meeting, and the facilities required for this purpose. (p. 37)

The Green Paper further recognizes that significant sport events can be linked with tourism through joint promotions with sport organizations. Once again. sport tourism is viewed solely within the events category. Activities such as adventure sports are classified as adventure tourism, yet they could also be classified as sport tourism as their primary motive for travel is adventure sports. While market segmentation is recognized as an important but complex matter, the author maintains that a broader conception of sport tourism is warranted. 
South Africa Sports Tourism Campaign

Besides the individual sport and tourism policy documents which mention sport tourism. South Africa Sports Tourism (SAST) was launched jointly by the Ministry of Environmental Affairs and Tourism in association with the Ministry of Sport and Recreation in October 1997 (Mokaba, 1997). He adds that this initiative is designed to be a prototype of how government-led. private sector driven and community based partnerships in tourism development can be effectual cost-saving enterprises through the combining of the resources of all pertinent stakeholders to promote travel to South Africa. SAST (1998) notes that the sponsorship agreement for the initial promotional campaign was signed by the DEAT Deputy Minister Mokaba. Minister of Sport and Recreation Tshwete and representatives of MasterCard and Parallel Media Group (PMG).

In examining the factors that have contributed to the selection of sport tourism as a theme. the importance given to major events is once again evident. The government contends that recent South African sporting activities such as the Cape Town 2004 Olympic Bid and Bafana Bafana (national soccer team) World Cup qualification have engendered a tremendous amount of global awareness of national sporting excellence which has to be capitalized upon immediately (SAST, 1998). The sport tourism theme was selected as a result of the following factors:

- The South Africa Football Association (SAFA) prepared a bid to host the 2006 World Cup Soccer event.

- Sport events and recreational activities attract tourism to regions that have not traditionally attracted geographical tourism. 
- Sport events generate global media exposure and can assist South Africa's position against its tourism competitors.

- Sport is distinctly understood by international companies as a means of achieving brand exposure through global media and therefore it is in a powerful position to attract and influence additional private sector investment to tourism promotion.

Moreover. the government highlights the economic benefits that recent sporting activities have contributed. The SAST initiative is an international multi-media campaign and was launched to ensure these benefits and exposures are exploited to their maximum potential. The following activities have been initiated since the launch of the campaign:

- The campaign television program, SA SportsAction. has been distributed to and transmitted in 49 countries.

- A web site. www.sportstourism.com. was launched on-line in April 1998.

- Incentive travel packages to South Africa were developed and promoted throughout the $3^{\text {rd }}$ quarter of 1998.

- In February 1998. the first in a series of SAST workshops was held to formulate systems of inclusion for national sport and tourism bodies. This workshop established the criteria by which specific events/activities would be chosen for promotion through SAST.

Despite the developments made in implementing SAST themes and objectives through particular programs, the campaign faces a number of barriers to its growth and success (SAST, 1998). SAST adds that these barriers include: 
- a lack of government financial support;

- a lack of communication between sport and tourism bodies; and

- a lack of forward planning and communication by tourism bodies.

Recently a representative of PMG noted that the SAST campaign, as a marketing platform. is back on track (C. Haber, personal communication, September 2, 1999). However, national government is no longer involved due to a lack of funding. While the sport tourism television program will be broadcast again. the web site is no longer online, and there have been no further workshops to formulate systems of inclusion for national sport and tourism bodies. Thus, the campaign as a whole has failed to strengthen the links between the sport and tourism bodies as initially anticipated.

It is further evident that when sport and tourism departments make reference to sport tourism. they do so independently of each other. What is even more disconcerting is that a joint sport tourism campaign has failed to integrate sport and tourism effectively. As it is unlikely that the tourism and sport ministries will merge in South Africa. the SAST campaign should aim to prevent the duplication of effort. which separate departments can create. Moreover, it is suggested that as these links for collaborative work tend to occur on an adhoc basis for particular projects, methods for ensuring that a more continual view of problems and opportunities is taken should be explored (Glyptis. 1991). Similarly, Weed \& Bull (1997) assert that this lack of liaison among tourism and sport policy makers lies against a framework of increasing research in the field commending the importance of greater linkages between the two spheres. Moreover, a recent survey concerning the potential development of adventure sport tourism in the 
Western Cape confirmed that there is a definite lack of communication and coordination between sport and tourism bodies concerned with adventure sport in the Western Cape (Swart. 1999a).

It is apparent that the various sport and tourism policy documents, including the SAST campaign is focusing almost exclusively on mega-events. Continual reference is made to events such as the Whitbread Round-the-World Yacht Race. the All Africa Games, the Cricket World Cup and the Soccer World Cup (SAST, 1998). Mega-events can be defined as an event of unusually large size or impacts (Getz, 1998). It is asserted that the separate sport and tourism policy documents should reflect a coordinated administrative approach to sport tourism. Moreover, other strategies should be incorporated into, or augmented in. the SAST campaign that will be just as beneficial to attract sport tourists to South Africa. This can be achieved in a number of ways, and while it is beyond the scope of this chapter to describe these various strategies suffice it to say that these sport tourism forms are not all encompassing but merely illustrate the potential of sport tourism.

An examination of sport and tourism policy documents in South Africa revealed that sport and tourism have not been effectively linked despite the increasing advocacy for such a link. Although a joint sport tourism campaign was launched, it failed to be implemented successfully. It is contended that the sport tourism campaign can be enhanced by focusing on all aspects of the sport tourism industry, instead of concentrating almost solely on mega-events. The SAST campaign can enhance the sport 
tourism industry in South Africa by assisting regional and local tourism and sport bodies in focusing their sport tourism strategies more appropriately. $\underline{\text { Sport Tourism Strategies }}$

A number of sport tourism strategies that have been effective in other countries are described in the following section. This author contends that South Africa can enhance the development and promotion of sport tourism if greater attention is given to these types of strategies.

Activity holiday centers.

Glyptis (1991) notes that there are numerous sport tourism strategies that can be utilized besides sport tourism events. For example, providing activity holiday centers. such as water sport centers and outdoor pursuit centers, in the form of accommodation and a supervised schedule of activity based at or near the facility can enhance both sport and tourism development. Glyptis adds that these centers are provided by the commercial sector in the United Kingdom. though the National Sports Centers owned and managed by the Sports Council have offered holiday programs and taster courses for all levels of ability in a wide range of pursuits. Training for sports on a more competitive level can also be included in these programs.

Sport camps.

Sport camps are hosted at resorts, universities, and in the countryside. and offer organized training sessions in a multitude of sports (Delpy, 1998). These camps range from traditional sports to the more adventurous types. Besides sport camps for youth, there is an increasing trend to provide family and adult camps. Delpy adds that fantasy 
sport camps have been particularly successful in capturing the adult market. She further notes that at fantasy sport camps adults have the opportunity to train with their favorite sport stars, with the coach of a popular team and/or at a famous sport venue.

\section{Sport tours.}

Another strategy that could be implemented is sport tours. The most obvious types of sport tours are those that allow sport fans to follow their team on the road or travel to major sport events. Sport Team Organisers, a tour operator in South Africa. were particularly successful in arranging tour packages for the visiting English supporters during the Millennium Cricket Test Series between England and South Africa. Secondary attractions that were capitalized on during the visitors' stay were sunset cruises, trips to popular resorts such as Sun City, scenic tours around the Cape Peninsula, and wineland tours, amongst others.

Encouraging sport tours for sport teams and clubs can also be used. For example. in the Netherlands, off-season holidays are offered for sport teams from abroad. Glyptis (1991) notes that visiting teams are provided with training facilities. the opportunity to take part in friendly matches with local teams, and to use the National Sports Center at Papendal and the Royal Netherlands Football Association Center at Zeist. It is further asserted that in addition to competing, youth sport tours provide opportunities for team members and their families/or friends to tour countries, cities and areas where the competitions are held (Manjone. 1998). Similarly, Turco and Eisenhart (1998) claim that youth sports (participants under 18 years of age) are attractive for host communities since they attract large visitor groups, typically comprised of family and friends of the young 
athletes. The above sport tourism strategies illustrate that sport tourism. if developed appropriately, has the potential to benefit society.

To maximize the benefits of sport tourism. sport and tourism professionals must fully understand the synergy of both the sport and tourism domains. Moreover. it is essential that sport and tourism stakeholders forge genuine partnerships to institute compatible policies. programs and provisions. The misperception of sport tourism as related almost exclusively to mega-events can be eradicated by taking a more holistic approach to sport tourism development.

Sport tourism as an economic development strategy.

Another significant challenge for sport tourism professionals is to develop sport tourism more effectively as an economic development strategy. South Africa has hosted a number of higher profile sport events since its re-admission to international sport. These include events such as the Rugby World Cup (1995). African Nations Cup of Soccer (1996). World Cross Country Championships (1996). Modern Pentathlon World Cup Final (1996), UCI Mountain Bike World Cup Downhill (1997) and the World Cup of Golf (1997). South Africa's use of sport tourism as an economic development strategy is limited as it focuses on major events only. Incorporating smaller and more regular events into the relevant sport tourism strategies can enhance the SAST campaign. These events may contribute more effectively to the long-term development and sustainability of South Africa's sport tourism industry. Getz (1998) contends that destination marketers should carefully consider developing a suitable and attractive portfolio of sport events in which the occasional mega-event is counterbalanced by embarking on lesser, infrequent events 
and frequent local or regional-scale events. It is apparent that many communities in South Africa can never aspire to host the world's largest events but they can nevertheless create a suitable niche in smaller scaled events as asserted by Getz (1998). No specific reference to smaller scaled-events and the promotion of sport tourism on a regional level is made in the SAST campaign.

It is necessary for sport tourism professionals to be able to understand the socioeconomic costs and benefits of sport tourism better. An expansive review of literature exists regarding the socio-economic costs of sport tourism events (Ritchie, 1984; Getz. 1989: Hall. 1989: Collins, 1991; Turco \& Eisenhart. 1998; Standeven \& De Knop. 1999). Recently, there has also been a focus on the environmental impacts of sport tourism (Standeven \& De Knop, 1999).

A continuum of economic benefits and costs exist for communities that host sport tourism events. These benefits include expenditures by sport tourists that consequently create local employment, personal income and subsequent re-spending within an economy. Sport tourism events may also internalize local income, inducing spending by residents at the expense of outside attractions. Economic cost impacts of sport tourism events include price inflation for tourism goods and services, as well as opportunity and substitution costs. Increases in crime, environmental degradation and disruption of residents' lifestyles and patterns may also yield economic costs.

It is beyond the scope of this chapter to detail all the socio-economic costs and benefits of sport tourism. Consequently, a table that summarizes the impacts of hallmark events is presented to illustrate the factors that communities need to consider prior to 
embarking on sport tourism as a destination strategy, particularly with regard to major events.

Table 1

Impacts of Sport Tourism Events

\begin{tabular}{|c|c|c|}
\hline Impact & Positive & Negative \\
\hline Economic & $\begin{array}{l}\text { Increased expenditures } \\
\text { New employment }\end{array}$ & $\begin{array}{l}\text { Price increases during } \\
\text { event } \\
\text { Real estate speculation } \\
\text { Underused sports and } \\
\text { associated facilities after } \\
\text { the event }\end{array}$ \\
\hline $\begin{array}{l}\text { Tourism/ } \\
\text { Commercial }\end{array}$ & $\begin{array}{l}\text { Increased awareness of } \\
\text { region as a travel or } \\
\text { tourism destination }\end{array}$ & $\begin{array}{l}\text { Acquisition of poor } \\
\text { reputation as a result of } \\
\text { inadequate facilities or } \\
\text { improper practices }\end{array}$ \\
\hline Psychological & $\begin{array}{l}\text { Increased local or } \\
\text { national pride and } \\
\text { community spirit } \\
\text { Increased awareness of } \\
\text { outsiders perceptions }\end{array}$ & $\begin{array}{l}\text { Tendency to defensive } \\
\text { attitudes regarding host } \\
\text { regions } \\
\text { Likelihood of } \\
\text { misunderstandings leading } \\
\text { to host/ visitor hostility }\end{array}$ \\
\hline $\begin{array}{l}\text { Physical/ } \\
\text { Environmental }\end{array}$ & $\begin{array}{l}\text { New or improved } \\
\text { facilities }\end{array}$ & $\begin{array}{l}\text { Environmental damage, } \\
\text { noise, litter, traffic } \\
\text { accidents } \\
\text { Overcrowding } \\
\text { (table continues) }\end{array}$ \\
\hline
\end{tabular}




\begin{tabular}{|c|c|c|}
\hline Impact & Positive & Negative \\
\hline Socio-cultural & $\begin{array}{l}\text { Permanent increase in } \\
\text { local interest and } \\
\text { participation in activity } \\
\text { associated with event } \\
\text { Strengthening of } \\
\text { regional traditions and } \\
\text { values }\end{array}$ & $\begin{array}{l}\text { Commercialization of } \\
\text { personal or private } \\
\text { activities and } \\
\text { inaccessibility of venues } \\
\text { Commodification } \\
\text { (changing culture for } \\
\text { touristic appeal and ease } \\
\text { of consumption) and } \\
\text { trivialization (simplifying } \\
\text { culture for touristic } \\
\text { consumption) } \\
\text { Excessive drinking by } \\
\text { visitors, increased thefts } \\
\text { and muggings, sexual } \\
\text { permissiveness and fan } \\
\text { violence } \\
\text { Modification of event or } \\
\text { activity to accommodate } \\
\text { tourism }\end{array}$ \\
\hline Political & $\begin{array}{l}\text { Enhanced international } \\
\text { recognition of region as } \\
\text { resort. or place to invest } \\
\text { Propagation of political } \\
\text { values held by } \\
\text { government and people }\end{array}$ & $\begin{array}{l}\text { Exploitation of local } \\
\text { people to satisfy } \\
\text { ambitions of political elite } \\
\text { Distortion of nature of } \\
\text { event to reflect current } \\
\text { political values }\end{array}$ \\
\hline
\end{tabular}

Note. Derived from Ritchie, 1984; Collins, 1991 and Turco, Riley \& Swart, in press. 
A summary of the potential impact that the hosting of the 2004 Olympic Games could have on the South African tourism industry was conducted by South Africa Tourism [SATOUR] in 1994. The main benefits that could accrue to South Africa included the further development of South Africa's infrastructure, and specifically the bidding, communications and tourism sectors. The positive influence of the publicity that Cape Town would receive would bring additional benefits. Some of the key issues that were associated with the costs of hosting the Olympic Games included capital investment costs. operational costs of hosting the events and the long-term costs of such an event (SATOUR, 1994).

From the above, it is evident that sport tourism destination planners have to employ strategies that maximize the benefits of sport tourism. while delimiting the costs. Ritchie (1984) suggests that a more balanced view of the costs and benefits are required. while Getz (1989) indicates that a community development perspective is required so that sport tourism enhances the host community's way of life, economy and environment.

Sport tourism professionals should be able to bid for events more effectively and host events more successfully. Despite the lack of expertise currently being experienced by South Africa society with regard to hosting major events. many leading cities in South Africa are continuing to bid to host these events. In fact, the Government has identified bidding as an area of weakness in the administration of South African sport (Government of South Africa: DSR, 1996). Moreover, this lack of expertise was evident in the failed Cape Town Olympic bid for the 2004 Games. It is acknowledged that South Africa has a credible history of hosting sport despite its isolation from international competition. 
However, one has to recognize that it still has to establish a successful track record of hosting world championship events in comparison to the other 2004 bidding cities such as Athens, Stockholm and Rome. It is contended that this lack of expertise in hosting major sporting events contributed to the failed 2004 Cape Town Bid. A successful track record of hosting sport events makes it easier for cities to secure subsequent events (Turco \& Eisenhart, 1998).

Collins (1991) notes that as more cities obtain facilities and experience to organize events. it becomes even more important for planners to ascertain why a bid should be made. It is well recognized that the bidding for major events has become very competitive. Hence it is necessary to justify the bid effort. knowing that there is likelihood for potential losses (Getz. 1998). He adds that this is an especially significant question for Olympics and other global-scaled event bids, as the bid effort can readily cost millions of dollars over a multi-year period. Getz further notes that agencies and communities considering major bids should do so with a strategy to achieve benefits to the community beyond the attainment of the hosting privilege. In hindsight it is contended that South Africa`s 2004 Olympic bid was premature and could have resulted in significant costs to the community when one considers South Africa's lack of expertise with the bidding and hosting of major international sport events.

This lack of expertise continues to be evident in the hosting of recent events such as the Afro-Asian football (soccer) international between South Africa and Saudi Arabia in Newlands. Cape Town and the All Africa Games in Johannesburg in 1999. One way of enhancing the sport tourism industry is the more efficient use of the existing sport 
tourism infrastructure. It was found that both the above-mentioned events were marred by inefficient use of infrastructure (personal communication, B. Walters. November 5. 1999). The failure to attract capacity crowds to an international football match at Newlands was apparent. A novel approach to marketing football events at Newlands should be attempted as it is a stadium traditionally used for rugby only. Organizational hitches at many of the events at the All Africa Games included accreditation. accommodation and volunteer problems, in addition to the lack of spectators (personal communication. B. Walters. November 5. 1999). Undoubtedly. these performance problems had an effect on the total experience of the sport tourism consumer. It is asserted that these examples illustrate that it is necessary to understand the sport tourism consumer from a sports perspective better. It is well recognized that consumer motives determine what people want to do and the extent to which they want to do it. When consumers feel, see or perceive a connection between their needs and the product or service offered incentives to follow-up develop. Consumers evaluate their incentives in terms of value for money and experiences to be gained or relived. For example, a weekend sports festival experience may induce a sport tourist to return the next year. It is also central to identify the benefits sought by sport tourists and the elements that appeal to various market segments, and to manage the needs of the sport tourist better.

One area that is particularly lacking in the sport tourism industry in South Africa is the evaluation of sport tourism. A case in point is the 2004 Cape Town Olympic Bid. Even though this was the first time South Africa was hosting three major world championships, no sport tourism research studies were undertaken to evaluate the success 
of these championships. One city that has been making a concerted attempt to evaluate the socio-economic impact of sport tourism events is Durban. However, the researchers acknowledge that they require assistance in improving their methods of evaluation. Moreover. little research is undertaken regarding resident's perceptions of sport tourism events and initiatives as well as promotional effectiveness research. It is apparent from the above discussion that there will be many occasions within the professional's career within the sport tourism industry that will call for sound research skills. In order to enhance the experience of the sport tourist as well as to maximize the potential of the sport tourism industry, it will be beneficial for sport tourism professionals to be able to evaluate sport tourism developments.

In summary the key performance problems within the South African sport tourism industry are:

- a lack of a holistic understanding of sport tourism;

- a strong focus on major events which is but one element of sport tourism;

- a lack of coordination and integration of sport and tourism at national and regional government levels;

- a lack of appropriate use of sport tourism as an economic development strategy:

- a lack of expertise in bidding and hosting sport tourism events;

- a lack of understanding of the sport tourism consumer: and

- a lack of sport tourism evaluation and research. 


\section{Education Problem}

Educational problems are identified by a discrepancy between actual and desired states of affairs (Robinson. 1993). The performance problems defined above are a function of the lack of formal provisions of sport tourism education in South Africa. With the sport and tourism industries moving closer together in recent years. educational establishments have been left short in meeting the requirements of industry to provide graduates who understand the consumer from a sports perspective. and with the ability to manage the needs of the sport tourist (Gammon \& Robinson. 1999). This is particularly apparent in South Africa as there are limited opportunities available for sport tourism education.

The absence of adequate education, training and awareness is found to be perhaps the greatest deficiency in the tourism industry in South Africa (Government of South Africa: DEAT, 1996). Furthermore, the Tourism White Paper recognizes that one of the main pillars of a new responsible tourism industry in South Africa is the development and investment in an education system that will lead to self-sufficiency and reduce reliance on imported skills.

Sport tourism has been acknowledged as a strategy to grow the tourism sector as a major force in the national economy. The Minister of Environmental Affairs and Tourism (personal communication, January 18,1998 ) confirms the significance of studies in sport tourism "since there is no doubt that this market segment holds tremendous growth potential for our country". There has been little emphasis on trade education, training and research although these aspects are identified as SAST campaign products. 
It is contended that the introduction of sport tourism education is desirable as it will contribute to a body of knowledge that is required for sustainable tourism to prosper in South Africa. The White Paper on Tourism (1996) concludes that the tourism industry would generate some R48 billion (\$US 8 billion) annually and create two million jobs if tourism contributed 10\% to the GDP (Gross Domestic Product) of South Africa as it does in the USA. In terms of its contribution to the development of a sustainable sport tourism industry, the introduction of sport tourism education is desirable.

\section{Curriculum Problem}

The education problem is a curriculum problem in that persons cannot get information, skills and dispositions necessary to participate effectively in the sport tourism industry. Only one sport tourism module is currently being offered at a university in South Africa. The importance of introducing sport tourism as a discipline at a post secondary education level is recognized by few sport and tourism departments. In 1999 an introductory sport tourism course was taught to tourism students in Cape Town. These students strongly contended that they were being denied an opportunity to be exposed to a niche market as sport tourism is not presently offered as part of their tourism studies. Moreover, there is a feeling that current sport management departments do not have the expertise in this field. In order for the SAST campaign to have a significant and sustainable impact on South African society, greater emphasis on education is required. The author contends that the development of a sport tourism curriculum (and ultimate 
implementation) will contribute to the sustainable development of the sport tourism industry in South Africa.

\section{Problem for Study}

The problem to be investigated in this study can be defined as the discrepancy between the lack of a sport tourism curriculum for a particular clientele, in a specific context. and with a specific content in South Africa and the desirability of establishing a sport tourism curriculum for a particular clientele. in a specific context. and with a specific content in South Africa.

It is apparent from the performance problems that there will be many occasions within the sport tourism professional's career in the sport tourism industry that will call for an understanding of sport tourism as well as an understanding of the issues prevalent in the sport tourism industry. They will also have to have the necessary skills to deal effectively with these issues. The designing of a sport tourism curriculum provides an opportunity for professionals to develop an understanding of sport tourism. specifically with regard to issues within the South African sport tourism industry. It further provides them with an opportunity to gain the necessary skills in order to enhance their performance within the industry. A sport tourism curriculum is necessary and justified in response to societal changes and to fit the requirements of contemporary South African society. 


\section{Curriculum Context}

The curriculum settings consist of "non-school" (adult and continuing education or business or government training and development) settings. As indicated in the educational performance problem above, those who are already in the profession should be able to perform better in order to enhance the South African sport tourism industry. Professionals within the sport tourism industry are employed in both private sector or business and government domains, therefore the above-mentioned "non-school" settings have been identified.

Contextual culture refers to the attitudes, beliefs, and values that are pervasive in the context (Dean. 1994). Ornstein and Hunkins (1998) contend that any discussion on curriculum should consider the social setting, especially the relationship between institutions and society, and its influence on curriculum decisions. It is necessary to describe the curriculum context within the broader context of post secondary education in South Africa. The importance of education to a sustainable tourism industry has been alluded to previously. The setting of post secondary education, specifically continuing education, as the proposed setting for the sport tourism curriculum was selected as it may offer professionals the opportunity to develop and transmit the appropriate skills to create relevant and useful knowledge. In this instance, post secondary education provides the labor market for sport tourism with high-level competencies and expertise necessary for the growth and prosperity of the economy. Just as the tourism industry has been profoundly shaped by its past, so too has the education system. Presently, a chronic mismatch exists between post secondary education output and the needs of a modernizing 
economy (Government of South Africa: DET, 1996). It further adds that there is a shortage of highly trained graduates in various fields, largely as a result of previous discriminatory practice. This has been detrimental to the economic and social development as evidenced in the tourism industry reported previously.

According to the Government's Green Paper on Education (1996). one of the primary objectives in post secondary education in South Africa will be to produce the skills and technological innovations necessary for successful economic participation in the global market. Education is said to contribute to the development. progress and perpetuation of a nation's culture (Wuest \& Bucher, 1995).

In lieu of the above-mentioned factors it is evident that developing a sport tourism curriculum may contribute to developing a sustainable tourism industry in South Africa. Sport is recognized as a viable economic development strategy in the global sport community. Consequently, the traditional sport-related jobs are expanding and many new jobs related to sport are also created. It is apparent that if South Africa wants to participate effectively in a rapidly changing national and global context. there is an obligation to prepare individuals better to meet the demands and challenges of the contemporary sport tourism industry.

Significant Features of the Curriculum Context

The clientele, persons whom the curriculum process will serve, consists of learners (i.e., sport tourism professionals), as the context is "non-school" settings. The personnel, persons involved in the curriculum process, include the instructors at an operational level and the administrators at the managerial level. Resources that support 
the curriculum process consist of both financial and material resources. The publics or persons who can or could influence the curriculum process include actual publics such as the employers of institutions that will offer the curriculum. The culture or the institutional perspectives on the curriculum process may, to a large extent, be considered traditional. The department that offers the curriculum may tend to view this course as risk-taking that would conflict with customary practices of risk minimizing.

The clientele is important as it includes professionals concerned with continuing education in a "non-school" setting. It is necessary to consider how best to meet the requirements of the clientele. The clientele will be the adult learner as the curriculum is intended to resolve performance problems in the sport tourism industry. An understanding of adult learning principles is necessary. Learning is more than just the acquisition and manipulation of content, particularly for adult learners. In order for those designing adult learning to build more effective learning processes for adults. Knowles core principles of androgyny should be considered (Knowles. Holton \& Swanson. 1998). These core principles identified by Knowles et al. include:

1. the learner's need to know;

2. self-concept of the learner;

3. prior experience of the learner;

4. readiness to learn;

5. orientation to learning; and

6. motivation to learn. 
Significant Tasks in the Referent Situation

The type of tasks that sport tourism professionals should be able to perform well in the referent situation(s) for the curriculum, that is those setting in which they will be working, are based upon the evidence that professionals within the sport tourism industry require a sound understanding of sport tourism. They also require appropriate skills in order to minimize the performance problems in industry as described above. These tasks that students should specifically be able to do. but are now not done well in the referent situation. include the following:

1. Conceptualize "sport tourism".

2. Demonstrate best practice in developing, bidding and hosting of sport tourism events.

3. Demonstrate best practice in developing sport tourism initiatives.

4. Demonstrate best practice in developing sport tourism marketing plans for an event or destination.

5. Demonstrate an understanding of potential positive and negative impacts of sport tourism.

6. Demonstrate best practice in developing sport tourism strategies for destinations.

7. Demonstrate skills of evaluating sport tourism initiatives.

8. Demonstrate skills of written reporting of sport tourism problems and issues. 
Formulation

\section{Curriculum Problem to be Resolved}

Presently, there is no design for a sport tourism curriculum. Although political (institutional), administrative and personnel problems may affect the curriculum problem. curriculum change is not warranted on educational grounds unless a curriculum problem has been identified. In this instance there is no curriculum available for learners to refine their sport tourism skills and opportunities for curriculum, and ultimately instruction, should be available in order to contribute to better performance within the sport tourism industry.

The curriculum design problems will focus on the conceptual elements such as the intent and principles and instrumental elements such as the content and devices of the design. It is the curriculum designer's contention that there should be a design for sport tourism curriculum based upon the following intent and principles.

The intent of the curriculum design is to effect desired changes in how students think and how they act with regard to undertaking sport tourism. Students should be able to specifically do the following.

\section{Conceptualize "Sport Tourism"}

It is necessary to understand that "sport tourism" goes beyond the hosting of major events. Kurtzman and Zauhar (1997) identified five sport tourism categories according to distinct touristic endeavors. They include (a) events, (b) tours. (c) attractions, (d) resorts, and (e) cruises. They further note that the sport tourism activity can be competitive, recreational or both. Gammon and Robinson (1997) highlight the 
segmentalist structure of sport and tourism in order to outline further areas of focus. They classify a hard sport tourist as someone who specifically travels for either active or passive involvement in competitive sport. A softer definition of the sport tourist who specifically travels and who is primarily involved in active recreational sport for a sporting or leisure interest.

Getz (1998) offers a third model of sport tourism that connects the supply side of the sport tourism industry with the demand side. In the middle of the model, tourism intermediaries are the "connecting tissue" of the sport tourism industry. Intermediaries link the sport tourist with the event or destination in a variety of ways. Intermediaries are typically organizations that create sport events that attract tourists, or they help lure events to destinations such as convention and visitor bureaus. sport commissions and event corporations. These organizations often work in tandem with other intermediaries who are suppliers of hospitality and travel for the tourists.

Another model which views sport tourism from a supply and demand perspective is that of Turco et al. (in press). It provides an added dimension as it relates to the level of intensity which people are involved in sport tourism. The model serves to delineate between those people who are heavily involved in sport tourism and those who may have a peripheral interest. For example, within the core of the sport tourism supply and demand model are those visitors directly involved in the immediate sport as active participants. Spectators on the other hand have a close association with the sport (diehard fan) but may also have alternative activities that demand their interest, attention, time and money. Similarly, on the supply side participants are the focal attraction for the 
sport tourist. Organizers. managers and marketers of the sport event or destination are on the next level, while sport tour operators are on the outer most level. These models serve to depict the complexity of the sport tourism industry and illustrate that sport tourism goes far beyond the present perception of events.

Demonstrate Best Practice in Developing, Bidding and Hosting of Sport Tourism Events

Community support is integral to the survival of the industry, therefore finding ways to address community involvement is desirable. As indicated by Getz (1998). without continued public support. sport tourism events might not be viable. so there is a necessity to determine what are the best ways to involve multiple stakeholders in the developing, bidding, and hosting of sport events.

As indicated previously, the Government has identified bidding as an area of weakness in the administration of South African sport (Government of South Africa: DSR. 1995). South Africa still has to establish a successful track record of hosting world championship events in comparison to the other bidding cities. As noted previously by Turco and Eisenhart (1998), cities find it easier to secure subsequent event if they have a successful track record of hosting sport events. $\underline{\text { Demonstrate Best Practice in Developing Sport Tourism Initiatives }}$

It is contended that it is necessary for sport and tourism departments to work closer together to maximize the benefits of sport tourism. Standeven and De Knop (1999) site numerous examples of how sport is used to generate and sustain tourism and vice versa. A case in point is Disney World who has embarked on developing sport facilities to increase tourism. The Walt Disney International Sport Complex has facilities 
that cater for 25 sports. The primary purpose for the diverse range of venues is to attract a myriad of sporting events from age-group competition to professional sporting events (Leisure Opportunities, 1995). Another initiative worthy of illustration is that of the Belgian municipalities who used sport to promote tourism. In the 1980s. the Flemish bike route was established. Standeven and De Knop add that the route is a $641 \mathrm{~km}$ signposted loop through five Flemish provinces. Tourists can start anywhere on the route and can stay overnight at hiking huts, campsites and even hotels.

The use of tourism in the development of sport. while not a major focus of government, is nevertheless an important consideration. An increasing demand for the use of the natural outdoor environment for physical activity has led to an increase in built amenities and support infrastructure for access and usage. These developments have occurred worldwide and have been mainly tourist-targeted (Standeven \& De Knop. 1999). However, it is also recognized that they have provided additional facilities for local communities. For example. Standeven and De Knop found that a network of 20 Day Adventure Centers have been developed in New Brunswick. Canada which offer a variety of activities suited to a number of different skill levels and interests. These examples serve to illustrate the potential that exists to exploit tourism for the benefit of sport development and vice versa. The challenge, however, is to forge greater coordination for sport and tourism policies and programs. 
Demonstrate Best Practice in Developing Sport Tourism Marketing Plans for an Event or

Destination

It is apparent that consumer motives determine what people want to do and the extent to which they want to do it. Incentives to follow up develop when consumers feel. see or perceive a connection between their needs and the product or service offered. Consumers appraise their incentives according to value for money and experiences to be gained or relived. For example. a weeklong sports experience such as the Beach Africa Festival that takes place in Durban in July may induce a sport tourist to return the following year. It is further beneficial to be able to identify the benefits sought by sport tourists and the elements that appeal to various market segments. Turco et a!. (in press) note that the process of buying a sport tourism experience is a complex one. It is affected by countless variables that individuals never consciously consider but they impact their decisions. Much of the buying decision is shaped by motivations, attitudes and constraints to travel. Much of what sells in the realm of sport tourism relate to consumers' interests and motivations but it also relates to the amount of information they have. It is here that information supply, promotions and the media are very important. Demonstrate an Understanding of Potential Positive and Negative Impacts of Sport $\underline{\text { Tourism }}$

Numerous examples exist that allude to the costs and benefits of sport tourism, be they economic, socio-cultural or environmental impacts. Sport tourism destination planners have to employ strategies that maximize the benefits of sport tourism, while delimiting the costs. A more balanced view of the costs and benefits is recommended by 
Ritchie (1984). Getz (1989) adds that a community development perspective is required so that sport tourism enhances the host community`s way of life, economy and environment. Since the negative impacts of sport tourism events often tend to be glossed over by politicians, both the advantages and disadvantages of sport tourism events as well as developments have to be carefully considered. Standeven and De Knop (1999) note that if sport tourism is developed for economic gain without consideration to its other impacts, the likelihood exists for the true costs to greatly exceed its economic value. $\underline{\text { Demonstrate Best Practice in Developing Sport Tourism Strategies for Destinations }}$

It has been alluded to earlier that there are a number of sport tourism strategies that a community can utilize in order to market itself as a niche sport tourism destination. Getz (1998) contends that destination marketers should develop an appropriate portfolio of sport events in which the occasional mega-event is considered along with more frequent local or regional scale events. He adds that many communities can never aspire to host a major event but they can create suitable niche in smaller scaled events. Similarly, Turco et al. (in press) note that not every community is a sport tourism destination area (STDA) but with planning, adequate resource allocations and proper implementation. a community can become an attractive sport tourism locale. Demonstrate Skills of Evaluating Sport Tourism Initiatives

One area that is particularly lacking in the sport tourism industry in South Africa is the evaluation of sport tourism. Turco et al. (in press) note that the body of literature on sport tourism event evaluation is distinct with four themes emerging as important and timely to managers: (a) customer, (b) satisfaction research, (c) sponsorship evaluations, 
and (d) socio-economic impact assessments and host perceptions of event impacts. Tourist satisfaction is critical to the success of any sport tourism endeavor yet little research has been published in this area. Sport tourism field research present particular methodological challenges. There are numerous data collection techniques. each with its advantages and disadvantages. It is up to the evaluator to select the most appropriate method based upon the study's objectives, time, and available human and financial resources.

Demonstrate Skills of Written Reporting of Sport Tourism Problems and Issues

There has been very limited written reporting on sport tourism problems and issues in South Africa. In order to enhance the industry these problems and issues should be evaluated and reported by way of technical reports and research papers. It is contended that written reporting of the status of the sport tourism industry will act as a catalyst to enhance the industry in South Africa.

Principles that will guide the curriculum design process are linked to the adult learning principles mentioned previously. The instructional principles as outlined by Palmer and Rhodes (1997) articulated as curriculum principles for the purposes of this dissertation. include the following:

1. meaningful application;

2. manageable expectations;

3. performance examples;

4. active participation;

5. practice opportunities; 
6. knowledge of progress;

7. opportunities for choice;

8. opportunities for success; and

9. supportive environment.

Based upon the intent of the design to effect desired changes in how learners think and how they act with regard to undertaking sport tourism tasks and activities. the curriculum designer deemed these principles to be essential to the design. In terms of the principle of meaningful application, the tasks and learning activities will be related to situations to which the learners can reasonably expect to encounter in the sport tourism industry. In terms of the principle of active participation. learners will be personally involved and directly engaged in their particular sport tourism experiences since learning activities and tasks should enable students to participate actively in the learning process. In terms of the principle of opportunities for choice. the curriculum designer recognizes that students should be enabled to make choices about what they learn in order to encourage their participation in the learning activities and tasks. In terms of the principle of knowledge of progress, learners should have information on how well they are progressing. In terms of the principle of supportive environment. the curriculum designer recognizes that the curriculum context should be such that learners can get assistance in working through the problems they encounter during the sport tourism tasks. They may be threatened or discouraged by what they are expected to learn how to do. 
The intent of this particular curriculum design is to refine content knowledge of sport tourism. In this instance, the content of the curriculum design enables students to become more proficient with respect to a particular subject matter. namely sport tourism.

\section{Ways to Resolve the Curriculum Design Problem}

The curriculum's conceptual and instrumental design problems can be resolved by generating new resolutions. As there is no current curriculum design that addresses these design problems. new resolutions must be invented. A significant difficulty in generating new resolutions is that there is only a limited foundation for the curriculum design for sport tourism in South Africa. There is no way of knowing whether the design will work: that makes it difficult for stakeholders to buy into a new design which has not been tried and tested. The design could be revised on the basis of alpha (designer) and beta (controlled) testing but difficulties may be encountered during the process of gamma (field) testing in terms of "testing" a new design with learners.

Devise and Assess Alternative Resolutions for Each

Curriculum Design Problem

Edwards (1974) notes that the application of the criteria to the process of selecting between alternatives should be done carefully so that it is possible to defend the choice that is made. An ethical awareness of alternative consequences of the curriculum designer's actions is further required (Rowntree. 1982). There are a number of alternative resolutions that can be generated to address the curriculum design problems of intent and 
principles, and content. When designing a curriculum it is necessary to consider the elements of scope and sequence.

Scope generally refers to the breadth and depth of the curriculum content, and includes all the content, topics, learning experiences and organizing threads encompassing the education plan. When deciding upon the scope of the curriculum. the challenge of determining what knowledge is of most worth becomes an important question. The following alternative resolutions have been generated for the scope of the curriculum:

1. Design a curriculum that is academic and discipline-centered. In this way the learner is provided with the opportunity to become proficient with the subject of sport tourism.

2. Design a curriculum that is "non-school" and focuses upon specific skills. In this way the learner is provided with the opportunity to become proficient with specific skills required to function efficiently within the sport tourism industry.

3. Design a curriculum that focuses upon the participant concerns. In this design sport tourism content will feature the participants' interests, needs and desires.

The resolutions vary in terms of complexity as they may all not be feasible in terms of time, location and application. When dealing with scope, a significant challenge is the linking of all types of knowledge and experience within the curriculum plan. It is contended that by focusing on specific skills as described in resolution (2) compared to a discipline-centered curriculum design (resolution 1), the learner will have greater 
opportunity of linking sport tourism knowledge with on-the-job experience. Moreover, it may be virtually impossible to design a curriculum that focuses upon each participant's interests and problems.

It should further be considered that the clientele for whom the curriculum is being designed include professionals concerned with continuing education. thus focusing upon specific skills that will required to perform with the sport tourism industry is preferable. Furthermore. as Tanner and Tanner (1995) note that as teachers are the products of discipline-centered universities. they generally seem to ignore the requirements for curriculum synthesis on both the vertical and horizontal planes. As a result. the scope of each course is likely to be restricted to only a segment of the discipline or subject field of which it is a part.

In this instance. the curriculum designer deems resolution (2) as the optimum for the scope of the curriculum and resolution (1) as acceptable. It is further contended that (2) meets more of the criteria in terms of the intent and the principles of the design. in addition to being best possible for current professionals. It is considered the most suitable resolution for each design problem.

In order for the curriculum to encourage cumulative and continuous learning. attention is paid to the vertical relationship or the sequence of the curricular elements.

The following alternative resolutions have been generated for the sequence of the curriculum:

1. Design a curriculum that is hierarchical. In this way the learner moves from one class level to the next or from one course level to the next. 
2. Design a curriculum that is non-hierarchical. In this design. the sequence is based upon program designs or participant choices.

Tanner and Tanner (1995) note that the sequence of courses within a discipline or subject field are inclined to be arranged in a linear fashion irrespective if the sequence is sound. As the optimum resolution for the scope of the design was determined to be "nonschool", a linear design for the sequence of the curriculum is not applicable. A linear approach to curriculum design implies that education must be planned in a step-by-step manner, and hence a hierarchical approach to subject matter (Kelly, 1999). Learners are required to move from one class to the next or from one course to the next. In a "nonschool" environment it is necessary to consider adult learning principles such as "prior experience" and "opportunities for choice". hence each adult learner will undertake different types of sport tourism activities, at different times. A modular approach is therefore envisaged as adult learners will have the opportunity to choose those modules that are most relevant at a particular time or most relevant to the activities undertaken by the sport tourism professional. Young (1998) notes that modularization is a way of organizing small blocks of learning that can be combined in different ways. He adds that modularization also offers opportunities for choice and new combinations of study that can associate student purposes with the options a society has for the future. The optimum resolution for the subject matter is considered to be non-hierarchical.

It is further contended that the envisioned program design enables multirepresentation of content and interactive participation. Upon reviewing the types of activities that sport tourism professionals should do well, it is evident that the same type 
of content themes through the different modules. It is envisioned that the execution of the design will enable multi-representation of content and interactive participation as it is based upon curriculum principles such as practice opportunities. active participation and examples of expected performance.

Tanner and Tanner (1995) note that a controversial issue regarding sequence is whether it should be based on the logic of the subject matter or on the way in which individuals process knowledge. It is contended that a non-hierarchical program design provides an opportunity for interaction between content and the learner's interests. As mentioned previously. learners will have the opportunity to choose those modules that are directly relevant to their sport tourism professions, and hence the content will be based on prior experience which is an important adult learning principle. In other words, the tasks and learning activities will be related to situations to which the learners can reasonably expect to encounter in the sport tourism industry.

In this instance, the curriculum designer deems resolution (2) as the optimum for the sequence of the curriculum and resolution (1) as acceptable. It is further contended that (2) meets more of the criteria in terms of the intent and the principles of the design, in addition to being best possible for current professionals. It is considered the most suitable resolution for each design problem.

Select the Most Suitable Resolution for Each Curriculum Design Problem Resolution (2) for the scope and sequence of the curriculum may be more appropriate as it has the greatest potential to meet the intent and principles, and content of 
the proposed curriculum design for sport tourism. The optimum resolution is the most suitable as it is not feasible for learners concerned with continuous learning to be undertaking a discipline-centered curriculum that entails course levels. The optimum resolution is suitable on the basis that a non-school curriculum that provides a program design allows each learner an opportunity for choice (undertake tasks and activities that has direct relevance for the particular sport tourism professional). It provides for meaningful application (all tasks are based upon problems the professionals experience within the sport tourism industry) within a supportive environment as all professionals can share their experiences with each other.

\section{Execution}

\section{$\underline{\text { Realize the New Design }}$}

In order to determine the scope and sequence of the proposed sport tourism curriculum, the course of study will be outlined below. The content (scope) as well as the educational organization (sequence) will be described. Finally, an explanation as to why this particular scope and sequence has been chosen will be given.

Scope refers to all the content, topics, learning experiences and organizing threads comprising the education plan (Tyler. 1949). Ornstein and Hunkins (1998) note that when educators decide on what content to include in the curriculum, and the amount of detail to the content. they are engaged in considering the scope of the curriculum. Ornstein $\&$ Hunkins add that integration refers to the linking of all types of knowledge within the curriculum plan, and this is considered the major challenge when dealing with scope. 
Sequencing of the curriculum deals with organizing the content of the curriculum elements so that the curriculum fosters cumulative and continuous learning. The scope and the sequence of the sport tourism studies curriculum will be operationalized in modular form as outlined below. It is noted that "course of study" is the South African or British terminology for "curriculum". This usage is distinct from the American term "course" which refers to an individual course syllabus.

Sport Tourism Studies Curriculum (Scope and Sequence)

1. Overview of the Course of Study

To enhance the levels of performance of current professionals within the sport tourism industry, learners should develop a greater understanding of sport tourism. This course of study is designed to provide sport tourism professionals with such an opportunity.

Learners will receive supervision from the instructor but will be required to work independently on various tasks and activities such as reviewing the literature. consulting with other sport tourism professionals and disseminating research findings. Learners will meet during periodic discussion groups to review their tasks and present research findings.

2. Entry Characteristics

\subsection{The Learners}

Students must currently be employed within the sport tourism industry. 
2.2 Prerequisites

The only necessary prerequisites are that the modules selected must be of interest to the student and be related to situations encountered by learners in the sport tourism profession.

3. Expected Outcomes

3.1 Learners should be able to demonstrate knowledge of principal conceptions. elements and methods of sport tourism.

3.2 Learners should be able to demonstrate ability to conduct tasks and activities appropriate to an area of interest or specialization within the sport tourism industry.

3.3 Learners should be able to demonstrate ability to report the results of the projects undertaken.

4. Course of Study Goals:

Upon successful completion of the course of study, the learner will be able to:

4.I conduct a sport tourism literature review

4.2 develop a bid proposal for a sport tourism event or

4.3 develop a bid proposal for initiating a sport tourism

4.4 develop an organizational plan for hosting a sport tourism event or

4.5 develop a marketing plan for a specific sport tourism category 
4.6 analyze the costs and benefits of a sport tourism event or a sport tourism development

4.7 develop a sport tourism strategy for a destination

4.8 evaluate sport tourism initiatives

5. Topics

It is noted that as the curriculum is designed for adult learners. a flexible program design that increases accessibility for adult learners is required. It is recommended that each topic described below be offered as a module (or an individual course). While an adult learner can choose between different modules at any particular time. it is envisioned that module one is a prerequisite prior to enrolling in other modules. It is necessary to have a holistic understanding of sport tourism prior to engaging in more in-depth performance problems (prerequisite learning). Each module addresses a specific performance problem in the sport tourism industry. Learners have a choice between modules two and three and modules four and five as these modules will be specific to the sport tourism category the professional is currently working in.

5.1 Conduct a sport tourism literature review

(a) Library resources

(b) Electronic databases and searches

(c) Recommended journals

(d) APA format 
(e) Overview of sport tourism relationships

(f) Models of sport tourism

(g) The sport tourism industry

(h) The sport tourist

5.2 Develop bid proposal for a sport tourism event
(a) Examination of literature
(b) Draw on own sport tourism experiences
(c) Consult with recognized authorities in the field
(d) Consult with other sport tourism professionals
(e) Informal assessment of the need to host an event
(f) Formal appraisal of the need to host an event
(g) Event bidding considerations
(h) Evaluation of bidding procedures
(i) Future trends and considerations
(j) Disseminate research findings

5.3 Develop a bid proposal for initiating a sport tourism development
(a) Examination of literature
(b) Draw on own sport tourism experiences
(c) Consult with recognized authorities in the field
(d) Consult with other sport tourism professionals
(e) Informal assessment of the need to initiate a sport tourism development
(f) Formal appraisal of the need to initiate a sport tourism development 
(g) Proposal considerations for initiating a sport tourism development

(h) Evaluation of sport tourism development proposals

(i) Future trends and considerations

(j) Disseminate research findings

5.4 Develop an organizational plan for hosting a sport tourism event

(a) Examination of literature

(b) Draw on own sport tourism experiences

(c) Consult with recognized authorities in the field

(d) Consult with other sport tourism professionals

(e) Administrative plans for hosting a sport tourism event

(f) Financial plans for hosting a sport tourism event

(g) Legal issues and considerations for hosting a sport tourism event

(h) Community involvement strategies

(i) Quality service strategies

(j) Operations plans for hosting a sport tourism event

(k) Marketing plans for hosting a sport tourism event

(l) Sponsorship strategies

(m) Wrap up and evaluation strategies

(n) Factors related to poor events

(o) Future trends and considerations

(p) Disseminate research findings 
5.5 Develop a marketing plan for a specific sport tourism category

(a) Examination of literature

(b) Draw on own sport tourism experiences

(c) Consult with recognized authorities in the field

(d) Consult with other sport tourism professionals

(e) Factors to considered when developing a sport tourism marketing plan

(f) Sport tourism marketing mix

(g) Market segments

(h) Service quality

(i) Target markets

(j) Future trends and considerations

(k) Disseminate research findings

5.6 Analyze the costs and benefits of a sport tourism event or a sport tourism development

(a) Examination of literature

(b) Draw on own sport tourism experiences

(c) Consult with recognized authorities in the field

(d) Consult with other sport tourism professionals

(e) Economic costs and benefits

(f) Tourism/ commercial costs and benefits

(g) Physical/ environmental costs and benefits

(h) Socio-cultural costs and benefits 
(i) Psychological costs and benefits

(j) Political costs and benefits

(k) Avoiding negative impacts and maximizing the positive impacts of sport tourism

(l) Socio-economic impact measures

(m)Future trends and considerations

(n) Disseminate research findings

5.7 Develop a sport tourism strategy for a destination

(a) Examination of literature

(b) Draw on own sport tourism experiences

(c) Consult with recognized authorities in the field

(d) Consult with other sport tourism professionals

(e) Factors to be considered when developing a sport tourism strategy for a destination

(f) Market segments

(g) Service quality

(h) Target markets

(i) Sport tourism destination area characteristics

(j) Sport tourism resources

(k) Intelligence gathering

(l) Action planning

(m)Sport tourism development action planning strategies 
(n) Future trends and considerations

(o) Disseminate research findings

5.8 Evaluating sport tourism

(a) Examination of literature

(b) Draw on own sport tourism experiences

(c) Consult with recognized authorities in the field

(d) Consult with other sport tourism professionals

(e) Sport tourist satisfaction

(f) Sponsorship evaluation

(g) Issues in sport tourism evaluation

(h) Sport tourism evaluation methods

(i) Residents' perceptions of sport tourism

(j) Future trends and considerations

(k) Disseminate research findings

6. Devices

The eight modules are outlined below.

Module 1: Conduct a sport tourism literature review

Module 2: Develop bid proposal for a sport tourism event

Module 3: Develop a bid proposal for initiating a sport tourism development

Module 4: Develop an organizational plan for hosting a sport tourism event 
Module 5: Develop a marketing plan for a specific sport tourism category

Module 6: Analyze the costs and benefits of a sport tourism event or a sport tourism development

Module 7: Develop a sport tourism strategy for a destination

Module 8: Evaluating sport tourism

6.1 Content organization of each module

The topic for each module as described above is the organizing element for each module. In addition, the project (described under participant tasks below) that has to be completed for each module reinforces the specific performance problem. In this way the curriculum is arranged so that the content is presented first as an overview so that learners are furnished with a general idea of the situation (whole to part learning). The elements or sub-components of each module are listed to guide the learner with possible options to consider when dealing with his or her specific project for each module. While the modules are distinct as they focus on a particular performance problem. when one reviews the sub-components of each module, it is evident that they are integrated and overlapping. 


\section{Participant Tasks}

\subsection{Readings}

For each module, participants are expected to complete readings in standard references on sport tourism. They are also expected to do such reading as is appropriate for the completion of the course of study.

For assigned readings, participants should be able to answer to the following questions:

1. What, if anything, could this reading contribute to the improvement of sport tourism for an individual?

2. What, if anything, could this reading contribute to the improvement of sport tourism at a collective, institutional level?

\subsection{Discussion}

Participants are expected to locate examples and illustrations relevant to the topics considered and to use these as contributions to group discussions.

\subsection{Assignments}

Participants are expected to complete such assignments that may be made during the course of study. These may include, but are not limited to. reports to class on projects undertaken, and observations of sport tourism practice. 


\subsection{Projects}

Participants are expected to complete one project per module.

Module 1:

Conduct a sport tourism literature review regarding the concepts, definitions and models of sport tourism. Locate examples and illustrations that pertain to your specific position within the sport tourism industry.

Module 2:

Select a bid proposal for a particular sport tourism event and evaluate in detail all the elements of the bid. Suggest ways in which the bid proposal could have been enhanced. Given that community support is an often neglected factor in the designing of sport tourism events. how would you seek their support and what groups would you involve?

Module 3:

Develop a bid proposal for initiating a sport tourism development within the specific sport tourism category you are presently working within. Evaluate the strengths and weaknesses of your proposal, and describe what steps you would take to improve your proposal. 
Module 4:

Develop in detail an organizational plan for hosting a particular sport tourism event and evaluate ways in which the organization of the event can be improved upon by focusing specifically on "problem areas" that you may encounter in your community.

Module 5:

Develop and evaluate in detail a marketing plan for the specific sport tourism category you are presently working within. Identify the factors considered in developing the plan and the market research that was undertaken to develop the plan.

Module 6:

Select a particular sport tourism event or development in your community and analyze the costs and benefits of the event or development. Describe ways in which the negative impacts can be minimized and the positive impacts enhanced.

\section{Module 7:}

Develop a sport tourism strategy for a particular destination. Identify and justify which strategy would be most appropriate to your community. 
Module 8:

Select a particular sport tourism event or development in your community.

Describe the research procedures you would undertake to evaluate the socioeconomic impact of the event or development as well as its promotional effectiveness. Implement the procedures as well as present and evaluate the research findings.

\subsection{Reports}

Participants are expected to:

1. Prepare reports on assignments as requested.

2. Prepare reports on the projects undertaken.

3. Submit reports to the instructor. Reports are due on dates as announced.

\subsection{Performance Evaluation Procedures}

The extent to which participants fulfil the expected outcomes for the course will be judged through the quality of performance on the tasks undertaken. e.g. readings. discussions, projects and reports. Evidence of reflective thought informed by knowledge of sport tourism theory and practice is expected in all participant activities. Opportunity for self-evaluation will be provided through individual conferences as requested.

\section{Timeframes and Scheduling}

A module is usually designated by the number of hours of learning that is learner is expected to undertake (Jarvis, 1995). The modular option has been chosen so that 
there is more student choice. Learners will also be able to complete more modules over a shorter period of time in comparison to courses that are limited per term. It is envisaged that one module will be completed within eight weeks which is equivalent to two modules per term.

Explanation for selected scope and sequence.

This particular scope and sequence has been chosen for a number or reasons. The intent. principles and content identified in the curriculum design problems to be resolved were addressed in the new design. The overview. entry characteristics, expected outcomes, course goals, topics. devices. participant tasks. timeframes and scheduling. and curriculum delivery format of the curriculum represents a synthesis of the most suitable resolution. As indicated by the overview and expected outcomes, the intent of the curriculum design is to effect desired changes on how students think and act with regard to undertaking sport tourism tasks. Moreover, these desired changes are also desirable if learners can conduct sport tourism tasks in a manner in which self-realization as well as social benefit is maximized. In other words, by providing a curriculum that enables learners to develop sound sport tourism skills, this will in all likelihood contribute to them being adequately prepared for their careers in sport tourism. In so doing, there will be many benefits to the community as outlined previously.

In the overview, the principle of meaningful application is alluded to in the following extract: "To enhance the levels of performance of current professionals within the sport tourism industry, learners should develop a greater understanding of sport 
tourism. This course of study is designed to provide sport tourism professionals with such an opportunity."

The principles of active participation and knowledge of progress underlie the following: "Learners will receive supervision from the instructor but will be required to work independently on various tasks and activities such as reviewing the literature. consulting with other sport tourism professionals, and disseminating research findings." Finally. the principle of supportive environment is indicated in the overview by the following: "Learners will meet during periodic discussion groups to review their tasks and present research findings."

The entry characteristics further reflect the principles of meaningful application as well as opportunities for choice: "modules selected must be of interest to the student and be related to situations encountered by learners in the sport tourism profession."

The expected outcomes of the course of study, and specific course gnals are geared towards learners becoming more proficient with sport tourism. The topics. devices (modules) and participant tasks enable learners to demonstrate knowledge of principal conceptions. elements and methods of sport tourism. Therefore the curriculum on the whole will enable learners to demonstrate ability to conduct tasks and activities appropriate to an area of interest or specialization within the sport tourism industry undertaken. Moreover, it enables them to demonstrate the ability to report the results of the projects undertaken. Following adult learning principles. learners are provided with an opportunity of choice in terms of the modules and projects selected as well as the method of disseminating research findings. 
The curriculum is designed in the format of modules so that learners are provided with opportunities to only complete manageable tasks. Modules also reflect a flexible program design that increases accessibility for adult learners. Module one is a prerequisite course as the author contends that it is necessary for sport tourism professionals to develop a holistic understanding of the sport tourism industry in order to maximize its potential in benefiting society. Each module focuses around a particular performance problem that the sport tourism professional is likely to encounter. This allows for both security and independence in the learning context.

The topic for each module is the organizing element for each module. In addition, the project that has to be completed for each module reinforces the specific performance problem. The topic addresses each specific performance problem. The curriculum is arranged according to the principle of whole to part learning as learners are furnished with a general idea of the situation. The elements or sub-components of each module are listed to guide the learner with possible options to consider when dealing with his or her specific project for each module. While the modules are distinct, it is evident that the sub-components of each module are integrated and overlapping.

The modules reflect the content of the curriculum design which is provided in order to enable learners not only to become more proficient with the subject matter of sport tourism but also to enable learners to implement best practices in their respective professions. The modules address the following curriculum design problems: conceptualize what is sport tourism, demonstrate best practice in developing, bidding, and hosting of sport tourism events, demonstrate best practice in developing sport 
tourism initiatives. demonstrate best practice in developing sport tourism marketing plans for an event or destination, demonstrate an understanding of potential positive and negative impacts of sport tourism, demonstrate best practice in developing sport tourism strategies for destinations, demonstrate skills of evaluating sport tourism initiatives and demonstrate skills of written reporting of sport tourism problems and issues. By presenting these performance problems in a modular form. adults are provided with the opportunity of solving immediate problems as it is the focus of each module.

Knowledge of progress and a supportive environment is further illustrated in the participant tasks and evaluation procedures. Learners can report on the progress of their projects as well as contribute to class discussions. Opportunities for self-evaluation are provided as well.

The timeframe and scheduling is based upon the modular approach to curriculum. It allows for more student choice and learners will also be able to complete more modules over a shorter period of time in comparison to courses that are limited per term. In order to provide adult learners with manageable tasks, learning tasks must be arranged systematically and the author contends that the modular options take this principle into consideration.

At this stage it is necessary to consider the delivery format of the new curriculum. It is noted that post secondary education will be challenged to design more flexible and creative instructional formats (Edington. Davis \& Hensley. 1994). Wiles (1999) adds that as we move into the twenty first century the entire domain of instruction is shifting toward a more technological delivery of the curriculum. Investigation into technology- 
enhanced learning locates itself firmly within the goals of transformation, reconstruction and development set out by the democratic government of South Africa (Butcher. 1996). The author asserts that the new curriculum need not be "place- or time-bound" and that in the information age, "delivery" is a key component of curriculum design and development.

Sports Tourism Studies Curriculum (Delivery)

The optimum curriculum delivery format is considered to be the Internet as it will enable multi-representation of content and interactive participation. This resolution was favored above a classroom format or "in field" work experiences. The curriculum described above will be offered via the Internet. It is considered to be more appropriate as it has the greatest potential to meet the intent and principles, and content of the proposed curriculum design for sport tourism. The optimum resolution is suitable on the basis that the curriculum is provided within a flexible delivery system that can operate any time of the day in varying locations. It should be noted that the clientele for which the instruction is being designed include professionals concerned with continuing education. thus an Internet course will not require them to take leave from their present jobs for a period of time.

The Internet delivery format for Sport Tourism Studies provides for a more flexible instructional delivery system. The Internet-only course will provide learners with opportunities for experiential learning in a collaborative working environment. Since learners are required to work independently on various aspects, this course lends itself to 
experiential learning that can be provided by an interactive technology such as the Internet.

Explanation for chosen curriculum delivery format.

The sport tourism curriculum described above lends itself to an Internet delivery format. Following adult learning principles, the sport tourism program offered via the Internet would contain extensive opportunities for choice. Users can choose those activities that have direct relevance for their particular sport tourism category. for example bidding for sport tourism events or formulating a sport tourism strategy for a destination. Options to continue, to go back or forward can be provided throughout the program. Moreover, hyperlinks enables multi-representation of content, and users can control the pace and the sequence of the course. To help ensure that there are examples of expected performance, many case studies and examples can be provided in text and they can be viewed as many times the learner selects.

The proposed sport tourism program would enable adult learners to monitor their knowledge of progress by providing a "map" to show users what they have completed and the modules that still have to be completed. Practice opportunities would be provided as the learner constantly works on a particular sport tourism activity. and would be provided with comments from the instructor albeit not immediate.

The Internet may also be more appropriate as the selection of suitable media delivery for distance education is most effective when it matches the requirements of the content, learner and instructor. The approach to delivering the proposed sport tourism curriculum is "Use the right tools for the job philosophy" in which the primary learning 
modality will be the Internet. The objective of the course is to prepare learners currently pursuing careers in sport tourism to refine their sport tourism understanding and skills. The curriculum is designed to provide sport tourism professionals with such an opportunity. For each module, a course web site will be developed which provides announcements. a synopsis of the course, including specific course goals, required readings. student tasks, evaluation devices, grading scales and course polices. Assigned tasks will provide opportunities for enhanced learner/teacher interaction and student knowledge of progress. Learner/computer interaction will provide the opportunity for experiential learning whereby the students learn by experiential immersion in the various tasks and activities. Learners would demonstrate their writing skills by publishing their work to everyone in the course. Moreover, it will provide learners with an opportunity to learn within in a collaborative learning environment. Learner/learner interaction will be facilitated via class-specific newsgroups and email, whereby learners describe their particular sport tourism problem, and discuss their findings, and other experiences that they may have encountered. The Internet therefore provides multi-way learning channels that have the ability to weld students into experiential learning communities. It projects learning opportunities across time and space to learning communities who would otherwise be inaccessible. In this instance, the Internet appears to be the most suitable technology to encourage experiential learning specific to developing the learner's sport tourism skills.

A sport tourism curriculum offered via the Internet is further justified as distance education is an important part of post secondary education in South Africa. It 
compliments traditional approaches of educational materials by providing wider access. particularly to the disadvantaged (Center for Scientific and Industrial Research [CSIR], 1995). Consequently, it presents a way of opening up educational opportunities to all. For distance education to effectively play its role in contributing to the transformation of South African society. it faces a number of challenges. Distance is regarded as the major obstacle to enhancing the role of distance learning in South Africa (Ewing. 1995).

Distance, in this instance, refers to the fact that learners only receive material by post and work in isolation. Lack of learner support and contact, and poor quality materials are highlighted as concerns. This situation could in all probability contribute to the fact that institutions that currently provide distance education such as UNISA, Vista and Technikon South Africa face high failure and dropout rates.

Moreover, distance education faces the same socio-economic imbalances as conventional education in South Africa. A shortage of skilled teachers and a lack of adequate teaching and training facilities exist largely as a result of the apartheid policies of the previous regime. The CSIR (1995) point out that this situation renders a major opportunity for technology to play an important role in improving the quality of education.

Information technology is providing rapid access to the world's knowledge resources and this is having a major impact on societies socially, economically and politically. The Technology-Enhanced Learning Investigation (TELI) Team was commissioned by the Minister of Education to investigate the role of technology in distance education (Naidoo, 1996). Their report provides a framework for educational 
planners. Butcher (1996) maintains that the policy for the use of technologies in education and training embraces the framework of the first White Paper on Education and Training.

Furthermore, Butcher asserts South African education requires a new culture for information technology to improve the quality of education in South Africa. This culture should emphasize a commitment to a flexible learner-oriented approach. He advocates that suitable organizational. curricular, and instructional process ought to be in place so that technology can succeed in empowering learners.

The Telematics for Distance Education Consortium share the objectives of developing African resources and infrastructure to its full potential. It is using interactive distance learning as the optimal vehicle for kick-starting the information society in South Africa and the rest of the developing world (CSIR, 1995). In this way distance learning plays an instrumental role in the transformation of South African society. The CSIR note that pilot projects are being used to integrate multi-media based distance learning via Internet technologies. Pilot projects are being undertaken to ensure the successful integration of technology into education and training. This indicates that interactive multi-media technologies provide South Africa with the opportunity to create distance learning environments presently that have unparalleled empowerment potential.

As mentioned previously, learner support has been sorely lacking in the traditional approaches to distance learning. Current approaches have been found to be restrictive and inconvenient; limiting interaction between teacher(s) and students. With the advancement of technology, UNISA (a university who offers distance learning solely) 
has recently introduced on-line services for students (Ewing, 1995). Students are able to submit assignments and correspond with their tutors via e-mail. Moreover, to address the equity issue they are opening learning centers for students who do not have computer access.

West (1996) further describes how institutions and companies can collaborate to offer education on-line in developing countries. It can be viewed as another way in which the equity issue can be addressed. West adds that companies can make provision for shared Internet service to disadvantaged neighborhoods. This situation will further address additional learners' requirements such as e-mail. listserv`s and newsgroups that bridge the gap between tutors and learners as well as place learners in contact with each other. West concludes that they may not be studying the same subject but are linked by a common need for communication and equipment. It is apparent that distance learners are benefiting from increased contact via on-line services. On-line studies are rapidly becoming the prevalent way for individuals to study as opposed to the traditional, paperbased distance education in South Africa. Although it will be necessary to train teachers and learners to use the technology, instructional technologies provides the opportunity for instructional designers to enhance traditional correspondence schooling (McBeath \& Atkinson, 1992). Based upon the potential of on-line courses to improve instruction for the previously marginalized communities in South Africa, an Internet curriculum delivery system is justified. Offering the curriculum via the Internet is more cost effective than other instructional technologies such as videoconferencing. McBeath and Atkinson note that video-conferencing is a high-cost, high-risk technology presently. The Internet is 
further justified as the curriculum delivery format for this curriculum as it will be accessible to individual learners, anywhere and at any time (Bates, 1996).

Learner unfamiliarity with or reluctance to use the technology selected can be minimized in the following ways. Resource centers are currently being set up in South Africa in order to address the equity issue. These centers will be particularly useful for the working professionals who may not have access to the Internet at work. It will be necessary to ensure that tutors are available in order to familiarize potential learners with new technologies such as the Internet. Students enrolled at post secondary institutions have access to the Internet. It may be necessary to find out more about the comfort levels of potential students prior to them enrolling for the course (University of North Carolina. 1997). It will be necessary to provide ample opportunities for students enrolled in the class to provide comments and seek assistance (Aloia, 1998). Email, regular evaluations and conference areas will be incorporated into the design in order to provide learners with this opportunity. McGreal (1997) recommends that programs be accompanied by modules on how to learn in an on-line environment. A number of resources will be provided on site to introduce students to technology. Overall, the course web site will be designed to be as "user friendly" as possible for prospective students.

The issues around pedagogy and challenge of building virtual communities are formidable. However, we know that there are many potential learners awaiting the development of courses and programs in on-line format. Individuals challenged by distance, physical disabilities or those who welcome the opportunity to maximize their access to technology are some of the groups seeking out on-line learning opportunities. 


\section{Problem Resolution}

Based upon the intent, principles and content of the curriculum design problem. it is the curriculum designer's contention that the overview. entry characteristics. expected outcomes, course goals, topics, devices, participant tasks, timeframes and scheduling, and curriculum delivery format form a consistent and coherent whole in terms of attempting to resolve the curriculum design problem. Moreover, based upon the fact that there was no design that addressed the conceptual and instrumental elements of sport tourism studies. it is the curriculum designer's contention that the curriculum problem has been resolved.

The curriculum design is justified on the basis that it has the greatest potential to meet the intent and principles, and content of the proposed curriculum design for sport tourism studies in comparison to the other resolutions discussed previously. A nonhierarchical program design in the form of modules that are specific to performance problems in the sport tourism industry and offered via the Internet is required. The design is justified in terms of time, location and application as it meets the criteria of intent and principles of the design. in addition to meeting the criteria of least expensive and best possible for current professionals who are concerned with continuing education. The curriculum design for sport tourism studies is justified according to utilitarian principles whereby it attempts to resolve the curriculum design problems in a way that will meet most of the criteria and principles as explained previously. In addition, it benefits most students, with the intent of benefiting the community as a whole. The educational performance problem is resolved by providing a sport tourism curriculum to current 
professionals in the sport tourism industry so that they can enhance the performance of the sport tourism industry as a whole, and the associated benefits can accrue to the community.

\section{Review}

The curriculum designer can determine the quality of the design by assessing whether the design meets the criteria as described above (alpha testing). Alpha reviewing was carried out in both the preparation and formulation phases. Various participants such as curriculum design specialists, sport tourism instructors as well as professionals (sport and tourism department representatives, sport and tourism marketing agencies. as well as a sport tourism instructor) will be involved with beta reviewing on a limited scale. They can provide valuable insight in terms of refining the scope and sequence of the curriculum design. More persons would be involved in the review process if plans for implementation are likely. A sport tourism instructor and web designer can be consulted. Program content can be expanded. and the web site design reviewed A survey could be posted on a list-serv for sport tourism instructors, and they would be asked to comment on the design from the ultimate user's viewpoint. During field testing assessments can further be obtained from potential learners.

\section{Revision}

Based upon the review assessment, the design can be altered an improved upon. It will be necessary to take into consideration the following comments by sport and tourism 
professionals. In terms of the module. "Develop an organizational plan for hosting a sport tourism event", it was noted that a section should be included regarding ownership of the event (and associated risks), commercial programs. and City and event leveraging.

Another reviewer commented that while reading the design of the sport tourism curriculum that "at some stage I became perturbed about the impression I got that the ineffectiveness of the current sport tourism strategy stemmed mainly from the lack of expertise in South Africa to organize major events. I am, however, happy to mention that as I continued working through the document. my concerns were allayed by the fact that you actually managed to highlight the real cause, namely a lack of closer cooperation and a meaningful partnership between Sport and Tourism."

The final reviewer commented that while the sport tourism curriculum design was comprehensive. she indicated that the content or themes of the modules should be separated from the learning resources required. She further noted that the limitations of Internet usage at South African universities are underplayed. Careful consideration should be given to this aspect during the implementation phase. particularly with regard to assessment and quality control. 


\section{CHAPTER IV \\ SUMMARY, CONCLUSIONS AND RECOMMENDATIONS \\ The Problem Under Consideration}

As defined in Chapter I. the problem that formed the focus for this dissertation is the discrepancy between the lack of a sport tourism curriculum for a particular clientele. in a specific context. and with a specific content in South Africa and that the desirability of a sport tourism curriculum for a particular clientele. in a specific context. and with a specific content in South Africa.

\section{Objectives}

The objectives of this study were to:

1. Identify a curriculum design and development model appropriate for a sport tourism curriculum.

2. Describe the current status of sport tourism curricula.

3. Provide a rationale for developing a sport tourism curriculum.

4. Identify the specific context for the sport tourism curriculum.

5. Identify the particular clientele for the sport tourism curriculum.

6. Identify the specific content for the sport tourism curriculum.

7. Determine the scope of the sport tourism curriculum.

8. Determine the sequence of the sport tourism curriculum. 
9. Determine the delivery system for the sport tourism curriculum.

\section{Summary: Objective 1}

The research question related to the first objective was (1) what is an appropriate curriculum design and development model for a sport tourism curriculum? This question was answered through a review of the professional literature on the topics of curriculum design. curriculum design types and curriculum design considerations.

Curriculum design focuses on the ways in which a curriculum is produced, particularly the actual arrangements of the components of the curriculum plan (Ornstein \& Hunkins. 1998). In order to represent an understanding or set of assumptions of how things work. curriculum designers use various paradigms and models. Ornstein and Hunkins add that most curriculum designs are modifications or integrations of three basic design types: (a) subject-centered designs. (b) learner-centered designs, and (c) problemcentered designs. It is contended that these designs are limited as they load on a specific component of the curriculum. and each of the models represents a distinctive conceptualization of curriculum.

In terms of curriculum design considerations, it was noted that the components of a curriculum are viewed along several dimensions. These dimensions include (a) scope. (b) integration. (c) sequence, (d) continuity, (e) articulation, and (f) balance (Ornstein \& Hunkins. 1998). Scope generally refers to the breadth and depth of the curriculum content. A major challenge when considering the scope of the curriculum is the linking of all types of knowledge and experience within the curriculum plan. The linking of these 
activities is referred to as integration. The vertical relationship or the sequence of the curricular elements deals with encouraging cumulative and continuous learning. Continuity pertains to the vertical manipulation or repetition of curriculum components whereas the inter-relatedness of various aspects of the curriculum is referred to as articulation. and can be either vertical or horizontal.

Balance refers to the concern that appropriate weight is given to each aspect of the design in order to prevent distortions. These elements. particularly scope and sequence. are integral to designing a curriculum.

\section{Summary: Objective 2}

The research question related to the second objective was (2) what is the current status of sport tourism curricula? This question was answered through a review of the professional literature on the topics of sport tourism and sport tourism education.

Sport tourism is progressing encouragingly as an academic discipline worldwide. The sport tourism industry has recognized the importance of quality management throughout its operations and sectors. (University of Luton, 1998).

Gammon and Robinson (1999) contend that there has been tremendous growth in this domain over the last ten years that has left educational institutions lagging behind in meeting the requirements of industry. These requirements include the provision of trained graduates who understand the consumer from a trained sports perspective and with the ability to manage the needs of the tourist. Sport tourism professionals are required in a broad range of areas within the industry. 
A sport tourism curriculum is necessary to provide professionals with the opportunity to develop the knowledge and competencies required for employment within the sport tourism industry. Gammon and Robinson (1999) note that a core body of knowledge in sport tourism is still some way from being developed. They further assert that the key is identifying core aspects of sport tourism and synthesizing these within the local context of operation.

\section{Summary: Objective 3}

The research question related to the third objective was (3) what is the rationale for developing a sport tourism curriculum? This question was answered through a review of the professional literature on the topics of sport tourism and sport tourism education.

Given the limited research concerning sport tourism curricula. a study was conducted by Swart (1999b) to determine the scope of sport tourism courses, modules. programs or degrees that are currently being offered by academic institutions.

A descriptive research design incorporating the survey method was used for the purposes of investigating institutions offering sport tourism subject matter within their curriculum (Swart. 1999b). Respondents were asked to respond to a number of questions concerning the type of sport tourism academic offerings, the academic departments providing the content, the course titles, and number of courses.

The results of the study were analyzed to identify the geographical location of the institutions, the type of sport tourism academic offerings, the academic departments providing the content, the course titles which offer sport tourism content, the number of 
courses. and the date when these courses were instituted. In addition, core aspects of sport tourism offerings were further identified. The rationale, aims and objectives of these course offerings were also content analyzed.

The main geographical location of the institutions was the USA. Other countries represented in the sample include Belgium, Canada. United Kingdom, Australia, and South Korea. Forty-two percent of the respondents stated their institution offered sport tourism content. The most prevalent type of sport tourism academic offerings was in the form of modules within other courses $(78 \%)$, followed by course offerings $(56 \%)$ and sport tourism degrees $(40 \%)$.

The course titles indicate that there is a wide range of areas within the sport tourism industry. Students have the opportunity to gain the necessary foundational knowledge and skills, while being able to focus on a particular area of specialization. Some programs are highly specialized such as the tourism diploma program specific to the ski industry, among others. The course titles further indicate that there is a strong link to the management discipline.

Overall. the curricular rationale. aims and objectives of the sport tourism degree programs and courses are to introduce students to the field of sport tourism, and to prepare them adequately for performance in the sport tourism industry. The institutions recognize the growth of sport tourism in recent years, and the necessity to prepare students for a career in the sport tourism industry.

The recognition of the importance of sport tourism is reflected by the growing number of institutions who envision a need, and have plans to develop sport tourism 
curricular offerings in the future. This study illustrated the extent to which sport tourism has developed as an academic discipline. There is an increasing international interest and recognition of sport tourism as a niche market. Institutions are offering courses and degrees to meet the requirements of this new industry.

In terms of the analysis of sport tourism curricula with respect to curricular components of scope and sequence. the following observations were made. The scope of sport tourism curricula is diverse and is influenced by various factors such as institutional. departmental and other external factors. Both sport tourism degrees in the United Kingdom and Australia are specific to these contexts. Moreover, all sport tourism programs and degrees were strongly influenced by market-related factors in order to meet the requirements of this new industry, namely sport tourism. It is evident that determining what knowledge is most worth becomes a significant question when deciding upon the scope of the sport tourism curriculum.

Concerning the sequence of the sport tourism curricula described above, it is apparent that prerequisite learning and simple to complex learning is given prominence. The three degree programs start with foundational courses and then proceed to various areas of specialization. As universities tend to be discipline-centered. the design-type utilized in designing all the curricula described appears to be subject-centered. Moreover, the sequence of courses appears to be arranged in a linear fashion. even though this may not be the most appropriate sequence. Although both the sport tourism curricula implemented in the United Kingdom and Australia is specific to their particular cultural context, they both seem to be designed according to the "conventional" approach that 
draws upon applied psychology and educational craft wisdom for prescribing solutions to education problems. Gammon and Robinson (1999) note that knowledge and expertise were sought from various international institutions. An element of the "marketing" approach was also apparent as the curricula were based upon the perceptions of what the sport tourism industry wants or needs. The author contends that current sport tourism curricular offerings are deficient to meet the future requirements of the sport tourism industry within South Africa. It is necessary to design and implement a curriculum that will allow sport tourism professionals to resolve the performance problems within South Africa`s sport tourism industry.

\section{Summary: Objective 4}

The research question related to the fourth objective was (4) what is the specific context for the sport tourism curriculum? This question was answered through a review of the professional literature on the topics of sport tourism, sport tourism curricula. curriculum design and development, and adult and continuing education.

In order to identify the specific context for the sport tourism curriculum. it is necessary to identify the most suitable design methodology for the sport tourism curriculum. It is contended that problem-directed design or enterprise-directed design would be most suitable to design the sport tourism curriculum. The "model" or "conception" of instructional design that was utilized to develop the sport tourism curriculum is Problem-Directed Instructional Design (Byers \& Rhodes, 1998). Although it is essentially an instructional design model, this approach is favored as an alternative to 
conventional curriculum design models as described in the section above concerning the analysis of sport tourism curricula. The generic design is problem or solution oriented. One of the first steps of the problem-based methodology was to identify the specific context of the curriculum. The curriculum settings consist of "non-school" (adult and continuing education or business or government training and development) settings as professionals within the sport tourism industry are employed in both private sector/business and government domains.

It is also necessary to describe the curriculum context within the broader context of post secondary education in South Africa. Both the tourism industry and the education system have been profoundly shaped by it past. There is a shortage of highly trained graduates in various fields, largely as result of previous discriminatory practices. One of the primary objectives in post secondary education in South Africa will be to produce the skills and technological innovations necessary for successful economic participation in the global market. Sport has become a viable economic development strategy in the global sport community. This not only expands the traditional sport-related jobs but also creates many new jobs related to sport. It is acknowledged that if South Africa wants to participate effectively in rapidly changing national and global context. there is an obligation to prepare individuals better to meet the demands and challenges of the contemporary sport tourism industry. 


\section{Summary: Objective 5}

The research question related to the fifth objective was (5) what is the particular clientele for the sport tourism curriculum? The clientele, persons whom the curriculum process will serve. consist of learners (i.e., sport tourism professionals), as the context is "non-school" settings as described in the section above. The setting of post secondary education. specifically continuing education. as the proposed setting for the sport tourism curriculum was selected as it may offer professionals the opportunity to develop and transmit the appropriate skills and to create relevant and useful knowledge. In so doing, a problem-based sport tourism curriculum can contribute to enhancing the performance of professionals currently in the sport tourism industry.

As the curriculum is intended to resolve performance problems in the sport tourism industry, the clientele will be the adult learner. An understanding of adult learning principles is required. Knowles. Holton and Swanson (1998) assert that Knowles" core principles of androgyny enable those designing adult learning to build more effective learning processes for adults

\section{Summary: Objective 6}

The research question related to the sixth objective was (6) what is the specific content for the sport tourism curriculum? The content of the sport tourism curriculum is related to the key performance problems within the South African sport tourism industry. This includes the following aspects:

- a lack of a holistic understanding of sport tourism; 
- a strong focus on major events which is but one element of sport tourism:

- a lack of coordination and integration of sport and tourism at national and regional government levels:

- a lack of appropriate use of sport tourism as an economic development strategy;

- a lack of expertise in bidding and hosting sport tourism events:

- a lack of understanding of the sport tourism consumer: and

- a lack of sport tourism evaluation and research.

The curriculum design problems focuses on the conceptual elements such as the intent and principles and instrumental elements such as the content and devices of the design. It is the curriculum designer's contention that there should be a design for sport tourism curriculum based upon the following intent and principles.

The intent of the curriculum design is to effect desired changes in how students think and how they act with regard to undertaking sport tourism. Students should specifically be able to do. but are not now done well in the referent situation, include the following:

1. Conceptualize "sport tourism".

2. Demonstrate best practice in developing, bidding. and hosting of sport tourism events.

3. Demonstrate best practice in developing sport tourism initiatives.

4. Demonstrate best practice in developing sport tourism marketing plans for an event or destination. 
5. Demonstrate an understanding of potential positive and negative impacts of sport tourism.

6. Demonstrate best practice in developing sport tourism strategies for destinations.

7. Demonstrate skills of evaluating sport tourism initiatives.

8. Demonstrate skills of written reporting of sport tourism problems and issues.

Principles that guided the curriculum design process are linked to the adult learning principles mentioned previously. The instructional principles as outlined by Palmer and Rhodes (1997) articulated as curriculum principles for the purposes of this dissertation. include the following:

1. meaningful application;

2. manageable expectations;

3. performance examples;

4. active participation;

5. practice opportunities;

6. knowledge of progress:

7. opportunities for choice;

8. opportunities for success; and

9. supportive environment.

Based upon the intent of the design to effect desired changes in how learners think and how they act with regard to undertaking sport tourism tasks and activities, the curriculum designer deemed these principles to be essential to the design. The intent of 
this particular curriculum design is to refine content knowledge of sport tourism. In this instance, the content of the curriculum design enables students to become more proficient with respect to a particular subject matter; viz.. sport tourism.

\section{Summary: Objective 7}

The research question related to the seventh objective was (7) what is the scope of the sport tourism curriculum? The breadth and depth of the curriculum content is generally referred to as scope. and includes all the content, topics. learning experiences. and organizing threads encompassing the education plan. The following alternative resolutions were generated for the scope of the curriculum:

1. Design a curriculum that is academic and discipline-centered. In this way the learner is provided with the opportunity to become proficient with the subject of sport tourism.

2. Design a curriculum that is "non-school" and focuses upon specific skills. In this way the learner is provided with the opportunity to become proficient with specific skills required to function efficiently within the sport tourism industry.

3. Design a curriculum that focuses upon the participant concerns. In this design sport tourism content will feature the participants' interests, needs and desires.

The resolutions vary in terms of complexity as they may all not be feasible in terms of time, location and application. When dealing with scope, a significant challenge is the connecting of all forms of knowledge and experience within the curriculum plan. It 
is concluded that by focusing on specific skills as described in resolution (2) compared to a discipline-centered curriculum design (resolution 1), the learner will have greater opportunity of linking sport tourism knowledge with on-the-job experience. Moreover. it may be virtually impossible to design a curriculum that focuses upon each participants interests and problems.

As the clientele for whom the curriculum is being designed include professionals concerned with continuing education. focusing upon specific skills that will required to perform within the sport tourism industry is preferable. In this instance. the curriculum designer deems resolution (2) as the optimum for the scope of the curriculum and resolution (1) as acceptable. It is further contended that (2) meets more of the criteria in terms of the intent and the principles of the design. in addition to being best possible for current professionals. It is considered the most suitable resolution for each design problem.

\section{Summary: Objective 8}

The research question related to the eighth objective was (8) what is the sequence of the sport tourism curriculum? In order for the curriculum to encourage cumulative and continuous learning. attention was paid to the vertical relationship or the sequence of the curricular elements.

The following alternative resolutions were generated for the sequence of the curriculum: 
1. Design a curriculum that is hierarchical. In this way the learner moves from one class level to the next or from one course level to the next.

2. Design a curriculum that is non-hierarchical. In this design, the sequence is based upon program designs or participant choices.

As the optimum resolution for the scope of the design was determined to be "nonschool". a linear design for the sequence of the curriculum is not applicable. A linear approach to curriculum design implies that education must be planned in a step-by-step manner. and hence a hierarchical approach to subject matter (Kelly. 1999). Learners are required to move from one class to the next or from one course to the next. In a "nonschool" environment it is necessary to consider adult learning principles such as "prior experience" and "opportunities for choice", hence each adult learner will undertake different types of sport tourism activities. at different times. A modular approach is therefore envisaged as adult learners will have the opportunity to choose those modules that are most relevant at a particular time or most relevant to the activities undertaken by the sport tourism professional. Young (1998) notes that modularization is a way of organizing small blocks of learning that can be combined in different ways. He adds that modularization also offers opportunities for choice and new combinations of study that can link student purposes with the options a society has for the future. The optimum resolution for the subject matter is considered to non-hierarchical.

It is further contended that the envisioned program design enables multirepresentation of content and interactive participation. Upon reviewing the types of activities that sport tourism professionals should do well, it is evident that the same type 
of content themes through the different modules. It is envisioned that the execution of the design will enable multi-representation of content and interactive participation as it is based upon curriculum principles such as practice opportunities. active participation and examples of expected performance.

It is contended that a non-hierarchical program design provides an opportunity for interaction between content and the learner's interests. As mentioned previously, learners will have the opportunity to choose those modules that are directly relevant to their sport tourism professions, and hence the content will be based on prior experience which is an important adult learning principle. In other words. the tasks and learning activities will be related to situations to which the learners can reasonably expect to encounter in the sport tourism industry.

In this instance. the curriculum designer deems resolution (2) as the optimum for the sequence of the curriculum and resolution (1) as acceptable. It is further contended that (2) meets more of the criteria in terms of the intent and the principles of the design. in addition to being best possible for current professionals. It is considered the most suitable resolution for each design problem

\section{Summary: Objective 9}

The research question related to the ninth objective was (9) what is the delivery system for the sport tourism curriculum? In considering the delivery format of the new curriculum. cognizance was taken of the challenges of post secondary education to design more flexible and creative instructional formats as well as the shift toward a more 
technological delivery of the curriculum. Butcher (1996) notes that investigation into technology-enhanced learning locates itself firmly within the goals of transformation. reconstruction and development set out by the democratic government of South Africa. The author asserts that the new curriculum need not be "place- or time-bound" and that in the information age. "delivery" is a key component of curriculum design and development.

The optimum curriculum delivery format is considered to be the Internet as it will enable multi-representation of content and interactive participation. This resolution was favored above a classroom format or "in field" work experiences. The curriculum described above will be offered via the Internet. It is considered to be more appropriate as it has the greatest potential to meet the intent and principles, and content of the proposed curriculum design for sport tourism. The optimum resolution is suitable on the basis that the curriculum is provided within a flexible delivery system that can operate any time of the day in varying locations. It should be noted that the clientele for which the instruction is being designed include professionals concerned with continuing education. thus an Internet course will not require them to take leave from their present jobs for a period of time.

The Internet delivery format for Sport Tourism Studies provides for a more flexible instructional delivery system. The Internet-only course will provide learners with opportunities for experiential learning in a collaborative working environment. Since learners are required to work independently on various aspects. this course lends itself to 
experiential learning that can be provided by an interactive technology such as the Internet.

A sport tourism curriculum offered via the Internet is further justified as distance education is an important part of post secondary education in South Africa. It compliments traditional approaches of educational materials by providing wider access, particularly to the disadvantaged (CSIR. 1995). Butcher (1996) asserts South African education requires a new culture for information technology to improve the quality of education in South Africa. This culture should emphasize a commitment to a flexible learner-oriented approach. He advocates that suitable organizational, curricular, and instructional processes ought to be in place so that technology can succeed in empowering learners.

Based upon the potential of on-line courses to improve instruction for the previously marginalized communities in South Africa. an Internet curriculum delivery system is justified. Offering the curriculum via the Internet is more cost effective than other curriculum and instruction technologies such as videoconferencing. McBeath and Atkinson (1992) note that video-conferencing is a high-cost, high-risk technology presently. The Internet is further justified as the curriculum delivery format for this curriculum as it will be accessible to individual learners, anywhere and at any time (Bates. 1996). 


\section{Conclusions}

A curriculum designed to help resolve performance problems within South Africa's sport tourism industry would have the following principal features.

The specific context of the curriculum will be "non-school" settings. specifically continuing education. as professionals within the sport tourism industry are employed in both private sector or business and government domains. The particular clientele for the sport tourism curriculum will be sport tourism professionals. and hence adult learners.

The content of the sport tourism curriculum is related to key performance problems within South Africa's sport tourism industry. The intent of the curriculum design is to effect desired changes in how students think and how they act with regard to undertaking sport tourism. Principles that guided the curriculum design process are linked to adult learning principles and instructional principles as outlined by Palmer and Rhodes (1997).

The scope of the sport tourism curriculum is "non-school" and focuses on specific skills that the learner will require in the sport tourism industry. The sequence of the sport tourism curriculum is non-hierarchical and based upon program designs and participant choices. A modular approach is envisaged as adult learners will have the opportunity to choose those modules that are most relevant at a particular time or most relevant to activities undertaken by the sport tourism professional.

The curriculum delivery format for the sport tourism curriculum is the Internet. The Internet delivery format provides for a more flexible curriculum delivery system. 
The author contends that the principal features of the sport tourism curriculum listed above can help to resolve the performance problems that have been previously described. Based upon the intent, principles and content of the curriculum design problem. it is the curriculum designer's contention that the overview. entry characteristics, expected outcomes, course goals. topics. devices, participant tasks, timeframes and scheduling, and curriculum delivery format form a consistent and coherent whole in terms of attempting to resolve the curriculum design problem. Moreover. based upon the fact that there was no design that addressed the conceptual and instrumental elements of sport tourism studies, it is the curriculum designer's contention that the curriculum problem has been resolved.

The curriculum design is justified on the basis that it has the greatest potential to meet the intent and principles. and content of the proposed curriculum design for sport tourism studies in comparison to the other resolutions discussed previously. A nonhierarchical program design in the form of modules that are specific to performance problems in the sport tourism industry and offered via the Internet is required. The design is justified in terms of time, location and application as it meets the criteria of intent and principles of the design, in addition to meeting the criteria of least expensive and best possible for current professionals who are concerned with continuing education. The curriculum design for sport tourism studies is justified according to utilitarian principles whereby it attempts to resolve the curriculum design problems in a way that will meet most of the criteria and principles as explained previously. In addition, it benefits most students. with the intent of benefiting the community as a whole. The educational 
performance problem is resolved by providing a sport tourism curriculum to current professionals in the sport tourism industry so that they can enhance the performance of the sport tourism industry as a whole, and the associated benefits can accrue to the community.

The curriculum design of the "educational experience" for students in the sport tourism curriculum in a specific cultural context, namely South Africa was summarized in this chapter. The experience was designed in a form of a curriculum. "-Sport Tourism Studies". and the delivery format was modules via the Internet.

\section{Recommendations}

As the method used to design the sport tourism curriculum is an iterative process, the first recommendation would be to take into consideration the comments by sport and tourism professionals. In terms of the module, "Develop an organizational plan for hosting a sport tourism event". it was noted that a section should be included regarding ownership of the event (and associated risks), commercial programmes, and City and event leveraging.

Another reviewer commented that while reading the design of the sport tourism curriculum that “at some stage I became perturbed about the impression I got that the ineffectiveness of the current sport tourism strategy stemmed mainly from the lack of expertise in South Africa to organize major events. I am, however, happy to mention that as I continued working through the document, my concerns were allayed by the fact that 
you actually managed to highlight the real cause, namely a lack of closer cooperation and a meaningful partnership between Sport and Tourism."

The final reviewer commented that while the sport tourism curriculum design was comprehensive, she indicated that the content or themes of the modules should be separated from the learning resources required. She further noted that the limitations of Internet usage at South African universities are underplayed. Careful consideration to this aspect is required during the implementation phase, especially with regard to assessment and quality control.

The scope and sequence of the curriculum can be further refined by involving curriculum design specialists, sport tourism instructors as well additional sport tourism professionals in reviewing the design. The design would then require field-testing. Potential learners could be requested to volunteer to enrol in a module. This process has been implemented previously in South Africa where part-time tourism students volunteered to enrol in an introductory sport tourism course that was offered via videoconferencing and the Internet. This assessment could call for further design revisions that might improve the curriculum's appropriateness and effectiveness.

The biggest challenge to the designing of the sport tourism curriculum would be how the curriculum could be or should be implemented or "realized in practice". The author recommends that post secondary institutions in South Africa that offer sport and tourism education be approached to include "Sport Tourism Studies" as part of their curriculum offering. In order for the institution to offer the course, it will be necessary for the course to be accredited by the Tourism. Hospitality and Sport Education and Training 
Authority (THETA). THETA is responsible for promoting and facilitating training within the tourism sector, and has devised an accreditation framework to ensure that the education provided by all institutions is of a uniformly high standard (Witepski, 2001). The Department of Education is encouraging the registration of all providers of further education and training.

While the author contends that the basic design of the course is aimed at addressing key performance problems in the sport tourism industry. she recognises the implementation of the course could be altered by the accreditation requirements of THETA. In order to qualify for accreditation, a trainer must have a quality assurance program in place. provide ongoing professional development for staff and comply with legislative hygiene and government regulatory authority requirements. In addition. the trainer must provide outcomes-based training, or proof that a contract exists with another accredited organisation to conduct training and assessment on its behalf. Trainers must also be competent against TD306 training and development standards, and must have relevant industry experience. Finally, trainers must offer a National Qualification (NQ) or outcomes-based assessment, and assessors must be competent against TD301 and TD401 (Witepski, 2001).

It is recommended that the sport tourism curriculum designer. together with the sport and tourism instructors at the identified post-secondary institution "test" the design against THETA's requirements. Based upon the outcome of this process, the revised design could then be implemented. 
Finally, it is envisaged that "Studies in Sport Tourism" be implemented across post secondary institutions in South Africa as the final curriculum design would meet THETA`s requirements and the curriculum delivery format would enable collaboration amongst sport and tourism education providers in South Africa. A necessary step in the implementation process will be to determine how successful the program is. Although this type of inquiry is beyond the scope of this dissertation. it is recommended that research be undertaken to devise evaluation tactics. Implementation of the evaluation consists of employing information-gathering instruments such as surveys, case studies and interviewing. The results of this information search will assist in determining whether the realization of the sport tourism curriculum design in practice is successful in meeting learners ${ }^{\circ}$ requirements and attempting to resolve the performance problems in the South African sport tourism industry. 


\section{REFERENCES}

Aloia, G.F. (1998). Effective strategies for classes. [Online].

Available: htpp://cube.ice.net/ edutech/floridaweb/minimal.htm [1999. November 13].

Bates. A.W. (1996) The impact of technological change on open and distance learning. Open Learning - Your Future Depends on It. Brisbane, Queensland. [Online]. Available: htpp://bates/cstudies/ubc.ca/brisbanel.html [1999, November 11].

Blenkin. G.M. \& Kelly, A.V. (1987). The primary curriculum $\left(2^{\text {nd }}\right.$ ed.). London: Harper \& Row.

Bruner. J. (1960). The process of education. Cambridge. MA: Harvard University Press.

Butcher. N [South African Institute of Distance Education]. (1996). The use of technologies in education and training: South African policy perspectives. Technology Enhanced Learning Investigation (TELI). [Online]. Available: htpp://teli.mikom.csir.co.za [1998, February 10].

Byers. D.L. \& Rhodes, D. M. (1998). Interactive multimedia for training. Journal of Medical Education Technologies, 6 (4) 11-115

Centre for Scientific and Industrial Research. (1995). Improving the quality of education through technology. [Online]. Available: htpp://www.mikom.csir.za/ids/edu.html [1998, February 6].

Collins, M. (1991). The economics of sport and sports in the economy. Sport and tourism. In C. Cooper (Ed.), Progress in tourism. recreation and hospitality management. Vol. 3 (pp. 184-214). London: Belhaven Press. 
Dean, G.J. (1994). Designing instruction for adult learners. Malabar, FL: Krieger.

Department of Sport and Recreation: Western Cape (1995). A provincial policy framework. Draft Rainbow Paper - "Let's play and develop". Cape Town. RSA: Author.

Department of Sport and Recreation: Western Cape (1999). Strategic business plan (1999/2000). Cape Town. RSA: Author.

Delpy. L. (1996). Outlook for sport tourism - Olympics, Travel Outlook Forum 1996. Proceedings of the $21^{\text {st }}$ Annual Outlook Forum at the Travel Industry National Conference (pp. 120-126). Washington DC: Travel Industry Association of America.

Delpy, L. (1998). An overview of sport tourism: Building towards a dimensional framework. Journal of Vacation Marketing. 4(1), 23-38.

Dewey. J. (1916). Democracy and Education. New York: Macmillan.

Edington, C.R.. Davis, T.M. \& Hensley, L.D. (1994). Trends in higher education: Implications for health, physical education and leisure studies. Journal of Physical Education. Recreation and Dance. 65(7), 51-57.

Edwards, C.H. (1974). Readings in curriculum: A process approach. Champaign. IL: Stipes.

Eisner. E. (1994). The educational imagination. New York: Macmillan.

Ewing. D. (1995). The problem with distance education is - Distance. The Chronicle of Higher Education. Inc. [Online]. Available: http://chronicle.com [1998, February 6]. 
Franson, F.A. (1996). A design for an instructional device to rectify student misconceptions regarding projectile motion. Doctoral dissertation. Illinois State University, Normal, IL.

Gammon, S. \& Robinson, T. (1999). The development and design of the sport tourism curriculum with particular reference to the BA (Hons) sport tourism degree at the University of Luton. Journal of Sport Tourism. 5(2). Online. Available: http://www.free-press.com/journal/jst [1999. June. 10].

Gentry. D. (1991). Using interactive video to resolve a problem in teaching family/divorce mediators. Doctoral dissertation, Illinois State University, 1990. Dissertation Abstracts International, 51, 2970A.

Getz, D. (1989). Special events: Defining the product. Tourism Management. 10(2). 125137.

Getz D. (1998). Trends, strategies. and issues in sport-event tourism. Sport Marketing Quarterly. 7(2), 9-13.

Giles. H.H.. McCutchen, S.P., \& Zechiel, A.N. (1942). Exploring the curriculum. New York: Harper Row.

Glyptis. S.A. (1991). Sport and Tourism. In C. Cooper (Ed.). Progress in tourism. recreation and hospitality management. Vol. 3 (pp. 165-183). London: Belhaven Press.

Government of South Africa: Department of Education and Training. (1996). Green Paper on higher education transformation. Pretoria, RSA.

Government of South Africa. Department of Environmental Affairs and Tourism. (1996). White Paper: The development and promotion of tourism in South Africa. Online. Available: http://www.polity.org.za/govdocs/white_papers/tourism.html. [1997. September 5]. 
Government of South Africa: Department of Sport and Recreation. (1996). White Paper: A national policy framework "Getting the nation to play". Pretoria, RSA.

Hall, C.M. (1989). Hallmark events and the planning process. In Syme, G.J., Shaw, B.J.. Fenton. D.M. and Mueller. W.S. (Eds.), The Planning and Evaluation of Hallmark Events (pp.20-39). Aldershot: Avesbury.

Jarvis. P. (1995). Adult and continuing education. Theory and practice $\left(2^{\text {nd }}\right.$ ed.). London: Routledge.

Kelly, A.V. (1999). The curriculum. Theory and practice $\left(4^{\text {th }}\right.$ ed). Thousand Oaks, CA: Paul Chapman Publishing.

Knowles, M.S, Holton, E.F. \& Swanson, R.A. (1998). The adult learner: The definitive classic in adult education and human resource development $\left(5^{\text {th }}\right.$ ed.). Houston. TX: Gulf Publishing.

Kurtzman, J. \& Zauhar, J. (1997). A wave in time - The sports tourism phenomena. Journal of Sport Tourism. 4(2). [Online], Available: http://www.freepress.com/journal/jst/ [1998. February, 5].

Disney considers Olympic Games bid. (1995, August). Leisure Opportunities.1.

Maccia. E.S. (1965). Curriculum theory and policy. Presented at American Educational Research Associates. Chicago.

Manjone, J. (1988). International youth sport tour benefits. The Sport Journal. [Online], Available: http://www.thesportjournal.org/journal/voll nol/travel.htm [1998, October, 14].

Masteralexis, L.P.. Barr, C. \& Hums, M.A. (1998). Principles and practice of sport management. Gaitherburg, MD: Aspen Publishers. 
McBeath. C. \& Atkinson, R. (1992). Curriculum, instructional design and the technologies: Planning for educational delivery. Australian Journal of Educational Technology. 8(2), 119-131. [Online], Available: http://wwwasu.mirdoch.edu.au/gen/aset/ajet/ajet8/su92pl 19.html [1999. November. 11].

McGreal. R. (1997). The Internet: A learning environment. In T.E. Cyrs (Ed.), Teaching and learning at a distance: What it takes to effectively design. deliver. and evaluate programs. San Francisco, CA: Jossey Bass.

Mokaba P. (1997. October). Launch of South Africa Sport Tourism Theme Media Campaign. Speech by the Deputy Minister of Environmental Affairs and Tourism on the Occasion of the Launch of the Sport Tourism Initiative. Cape Town.

Morshead. R.W. (1995). Patterns of educational practice: Theories of curriculum. Ann Arbor. MI: The Pierian Press.

Naidoo. V. (1996). Acknowledgment. Technology Enhanced Learning Investigation (TELI). [Online]. Available: htpp://teli.mikom.csir.co.za [1998, February 10].

Ornstein. A.C. \& Hunkins. F. (1998). Curriculum: Foundations, principles and theory. Boston. MA: Allyn \& Bacon.

Palmer. T. \& Rhodes. D.M. (1997). An evaluative framework for selecting training multimedia. International Journal of Training and Development. 1(2): 128-135.

Parks. J.B. \& Zanger. B.R.K. (1990). Sports and fitness management: Career strategies and professional content. Champaign, IL: Human Kinetics.

Posner. G.J. \& Rudnitsky. A.N. (1990). Course design. (2 ${ }^{\text {nd }}$ ed.). NewYork: Longman.

Posner, G.J. \& Strike, K.A. (1976). A categorisation scheme for principles of sequencing content. Review of Educational Research. Fall, 301-406. 
Pratt. D. (1980). Curriculum: Design and development. New York: Harcourt Brace Jovanovich.

Ratcliff, J.L. (1997). What is a curriculum and what it should be? In J.G. Gaff, J.L. Ratcliff \& Associates. Handbook of the undergraduate curriculum: A comprehensive guide to purposes. structures. and change (1st ed., pp.5-29). San Francisco: Jossey-Bass.

Rhodes. D.M. (1990). Evaluation of instruction: A method. Unpublished manuscript. Illinois State University, Normal. IL.

Ritchie. J.R.B. (1984). Assessing the impact of hallmark events: Conceptual and research issues. Journal of Travel Research. 23(1), 2-11.

Robinson. V. (1993). Problem-based methodology: Research for the improvement of practice. Oxford. England: Pergamon Press.

Rowntree. D. (1982). Educational technology in curriculumdevelopment. London: Harper \& Row.

Slattery. P. (1995). Curriculum development in the postmodern era. New York: Garland Publishing.

Smith. O.B., Stanley, W.O. \& Shores. H.J. (1957). Fundamentals of Curriculum Development. New York: Harcourt Brace.

South Africa Sports Tourism. (1998). SAST: Campaign overview and status report. Cape Town. South Africa: Author.

South African Tourism. (1994). A summary of the potential impact that the hosting of the 2004 Olympic Games could have on the environment of the South African tourism industry. South Africa: Author. 
Sports Information South Africa. (1996). The estimated impact of sport on the South African economy. Pretoria: Author.

Standeven and De Knop (1999). Sport tourism. Champaign. IL: Human Kinetics Publishers.

Stenhouse. L. (1975). An introduction to curriculum research and development. London: Heinemann.

Swart. K. (1999a). Adventure sport tourism in the Western Cape. Unpublished manuscript. Illinois State University, Normal. IL.

Swart. K. (1999b). An assessment of sport tourism curriculum offerings at academic institutions. Unpublished manuscript. Illinois State University. Normal. IL.

Taba. H. (1962). Curriculum development: Theory and practice. New York: Harcourt Brace.

Tanner. D. \& Tanner. L. (1995). Curriculum development: Theory into practice $\left(3^{\text {rd }}\right.$ ed.). New Jersey: Prentice Hall.

Tennis. M. (1991). Instructional design for communication in nursing practices. Illinois State University, Normal, IL. Unpublished doctoral dissertation proposal.

Toombs, W. \& Tierney, W. (1991). Meeting the mandate: Renewing the college and departmental curriculum. (ASHE-ERIC Higher Education Report No. 6). Washington, D.C.: George Washington University, School of Education and Human Development.

Travers, R.M.W. (1964). Introduction to educational research. New York: Macmillan.

Turco. D. \& Eisenhart. H. (1998). Exploring the sport-tourism connection. Journal of the International Council for Health. Recreation. Sport \& Dance ICHPERD. 34(2): 25-27. 
Turco. D.M., Riley. R. \& Swart. K. (In Press). Sport tourism. Morgantown, WV: Fitness Information Technologies.

Tyler. R.W. (1949). Basic principles of curriculum and instruction. Chicago: University of Chicago Press.

University of Luton. (1998). BA (Hons) sports tourism validation document. Luton. England: Author.

University of North Carolina. (1997). Introducing students to technology. [Online]. Available: htpp://www.unc.edu/cit/tips/introducing.html [1998. February 10].

Weed. M.E. \& Bull. C.J. (1997). Integrating sport and tourism: a review of regional policies in England. Progress in Hospitality Research. 3(2), 129-148.

West. P. (1996). On-line education in developing countries. [Online]. Available: htpp://www.pgw.org/pw/et2000.html [1998, February 10].

Western Cape Department of Economic Affairs, Agriculture and Tourism (1999). Westem Cape tourism Green Paper. Cape Town: Author.

Wiles. J. \& Bondi, J. (1993). Curriculum development: A guide to practice $\left(4^{\text {th }}\right.$ ed.). New York: Macmillan.

Wiles, J. (1999). Curriculum essentials. A resource for educators. Needham Heights, MA: Allyn \& Bacon.

Witepski. L. (2001). Tourism Education: How do we measure up? The Journal of Southern Africa Tourism, 1(3): 89-95.

World Tourism Organization. (1991). Draft of the International Conference on Travel and Tourism Statistics: Ottawa Conference Resolutions. June 28, 1991. 
Wuest. D.A. \& Bucher. C.A. (1995). Foundations of physical education and sport. St. Louis. MI: Mosby-Year Book Inc.

Young, M.F.D. (1998). The curriculum of the future. From the 'new sociology of education' to a critical theory of learning. London: Falmer Press. 